\title{
Global Mapping of Indigenous Resilience Facing the Challenge of the COVID-19 Pandemic
}

\author{
Diosey Ramon Lugo-Morin (D)
}

\begin{abstract}
Postgraduate Program in Sustainable Management of Natural Resources, Management of Sociological Systems, Research and Posgraduate Studies, Intercultural University of Puebla State, Huehuetla 73475, Mexico; diosey.ramon@uiep.edu.mx
\end{abstract}

\begin{abstract}
Indigenous social development scenarios must be understood as the possibility of improving the sustainability of the planet and human health in the face of the COVID-19 pandemic. Integrating the institutional resilience approach by learning from the experience of indigenous peoples' informal institutions through the design of public policies can be a reality. To demonstrate the potential of this premise, a case study was conducted that examined the institutional resilience of one indigenous people, whose findings under nomothetic conditions may be useful for other territories around the world. These peoples provide lessons on how they cope with adversity, the COVID-19 pandemic being one of them. Institutional resilience is a step towards reaching out to the world's ancestral populations to learn from their knowledge. These scenarios can help us understand the implications of international policies on the capacities of nations to secure access to food and resources and, subsequently, to be better prepared for future pandemics.
\end{abstract}

Keywords: global; resilience; indigenous; SARS-CoV-2; knowledge; challenge

check for updates

Citation: Lugo-Morin, D.R. Global Mapping of Indigenous Resilience Facing the Challenge of the COVID-19 Pandemic. Challenges 2021, 12, 15. https://doi.org/10.3390/ challe12010015

Received: 25 April 2021

Accepted: 27 May 2021

Published: 31 May 2021

Publisher's Note: MDPI stays neutral with regard to jurisdictional claims in published maps and institutional affiliations.

\section{Introduction}

This study aims to explore the institutional resilience of indigenous peoples. A case study addresses the system of beliefs, values and traditions that emerges as a historical construct of institutional resilience. This indigenous people, faced with the challenge of COVID-19, have shown their resistance to the health crisis by configuring their food system.

The current pandemic will not be the last one that faces humanity, the capacity of resilience of the human being is put under test, the status quo not only configures its actions but also its behavior, proof of this is the current social metabolism of the global society [1-6]. Within the framework of this social metabolism, social acceleration stands out. Social acceleration attempts to show the progress of societies; for example, we have stable societies that have remained stable over time and we have societies that are advancing rapidly, such as Western societies [7]. The temporary stability of indigenous peoples has generated survival strategies to cope with the challenges of today's world (e.g., pandemics, climate change, wars, etc.), monitoring their informal knowledge and institutions can help to future challenges.

In the 40-year history of indigenous issues at the United Nations, and its even longer history at the International Labor Organization (ILO), timely thinking and dialogue are dedicated to the question of the definition or understanding of "indigenous peoples". However, no such definition has ever been adopted by any United Nations-system body [8]. One of the foremost cited descriptions of the definition of "indigenous" is an offer by Martínez Cobo's study on the Problem of Discrimination against Native People. After a protracted thought of the problems concerned, Martínez-Cobo [9] offered a working definition of "indigenous communities, peoples, and nations". He expressed some basic ideas forming the intellectual framework for this effort, including the right of indigenous peoples themselves to define what and who indigenous peoples are. The operating definition reads as follows: 
Indigenous communities, peoples, and nations are those which, having a historical continuity with pre-invasion and pre-colonial societies that developed on their territories, consider themselves distinct from other sectors of the societies currently prevailing on those territories, or elements of them. There are approximately 476 million indigenous people worldwide, in over 90 countries [10,11]. Indigenous communities since ancient times have been able to adapt to different realities; one example is the re-valorization of traditional food knowledge in response to the health crisis caused by the COVID-19 pandemic [12]. The institutional resilience that indigenous peoples possess has allowed the development of strategies to face the COVID-19 pandemic, a case study shows these strengths and how it could be replicated in other territories.

The problem addressed by this study is associated with one of the most important challenges of today: the COVID-19 pandemic, declared a pandemic by the World Health Organization on 11 March 2020 [13]. Reports from the World Health Organization (WHO) do not show a slowdown in a pandemic, on the contrary, infections, and deaths increase dramatically $[14,15]$. The occurrence of COVID-19 has become a threat to the global population [16]. The vaccine option is a reality, but only high-income countries and a few middle-income countries have access to vaccines. Many developing countries still do not have a vaccine for their populations [17-19]. Low-income countries only have the option of vigorously implementing infection control measures to prevent the spread of SARS-CoV-2 through human-to-human transmission [13]. Today's COVID-19 pandemic has overwhelmed society's capacity to respond [20-23].

The world has faced several pandemics in the past and humanity, with every pandemic that emerges, learns $[24,25]$. In this context indigenous peoples due to their perception of the world have learned to cope with a variety of challenges including disease and pandemics. History teaches us that indigenous peoples have built their worldviews due to long periods of observation of their environments [26-28]. Some studies attempt to understand these world views and have focused on identifying and analyzing indigenous peoples' systems of beliefs, values, and traditions with findings that highlight institutional resilience [29,30]. For example, the study by Lugo-Morin [30] shows how institutional resilience is an important element in the continuity and strengthening of their reproduction strategies. The implementation of public policies within the framework of indigenous groups' belief systems, values, and traditions opens up a range of possibilities for vulnerable territories to think about their development based on how they view the world in which they live [31].

Facing the COVID-19 pandemic, indigenous peoples have implemented response strategies based on their ancestral knowledge and informal institutions. Since ancient times, humanity has benefited from nature [32]. According to Raskin et al. [33] the relationship between man and nature has generated an interdependent process that today we see as a socioecological system. In a socioecological system two components interact. In the first one we find human beings with their ideas (beliefs, values, and traditions) and institutions (political, social, economic). In the second, we locate nature with both its biotic and abiotic side.

The rapid expansion of humanity has impacted the planet [34]. A new world order will necessarily have to rediscover the dependence on locally produced products and the importance of indigenous knowledge [35]. A change in preferences will not be easy; the pandemic is teaching us lessons, aimed at designing and implementing policies that promote self-sufficient and sustainable local natural resource economics [36].

In the last 250 years humanity has grown at an alarming rate to more than 7.7 billion people [37], the exploitation of natural resources is increasing generating a decline in sinks at a global level and with them an increase in $\mathrm{CO}_{2}$ [38]. The previous information is supported by the Intergovernmental Panel on Climate Change (IPCC) and the pressure on natural resources is a reality that is impacting negatively on the biosphere. Climate change and pandemics will slow down the global economy generating more poverty and 
disrupting food security. However, local food systems from the perspective of indigenous peoples can be opportunities [39].

To show the importance of institutional resilience and its constitutive form (informal institutions), the indigenous person as an original inhabitant of a territory has configuring attributes (for example, in its historical persistence, culture plays a determining role). However, the individuality is part of a collective or community which in turn is responsible for the cultural reproduction of the indigenous group. In this logic, we can visualize, for example, how food systems reflect the cultural reproduction that ultimately perpetuates identity. A food system in the ancestral context allows us to go through beliefs, values and traditions, it shapes informal institutions and is the basis for an indigenous people to face any challenge. In this sense, indigenous peoples, builders of their resilience, their historical persistence and their institutions are defining elements in today's global society.

Resilience is the ability to cope with an event, trend, or disturbance by responding or reorganizing to adapt, learn and transform [39]. According to Gunderson et al. [40] resilience is eclectic, defined as efficiency, coherence, persistence, change or uncertainty. On the other hand, Walker et al. [41] maintain four aspects to be considered in their conceptualization: latitude, resistance, precariousness, and panarchy. Resilience is having the ability to continue learning, self-organizing, and developing in dynamic environments when faced with uncertainty and the unexpected. In this logic, institutions (formal and informal) are relevant because they give meaning to human actions $[42,43]$.

The term "institutions" acquires relevance because it gives meaning to the "informal institution" which in turn constitutes the shaping element of institutional resilience. According to North [44], institutions are defined as a set of formal and informal constraints, created by human beings or arising spontaneously from their relationships, and mechanisms to enforce their agreements. Formal constraints are written rules, such as constitutions, laws and contracts, the modification of which involves varying degrees of difficulty. Such rules, which regulate exchanges and define property rights, create incentives for individuals to act. Individuals with common interests group together in organizations in order to take advantage of the opportunities created by institutions. Informal constraints are culturally inherited customs, traditions, conventions and codes of conduct.

Informal institutions are rules that are born within a social group in order to regulate the relationships and actions of its individuals. These rules have continuity because they are inherited historically. According to North [44], these institutions extend to customs, traditions, and codes of conduct. The positions of $[45,46]$ regarding informal institutions is to observe them as a system of symbolic relations; these authors argue that everyday life is the expression of institutions in their informal form.

Building on the definition of informal institutions, institutional resilience is defined as the capacity to adapt or transform a system of beliefs, values and institutional arrangements in a specific territory. This adaptation or transformation is driven by historically inherited cultural expressions that, in most cases, create environments that result in individual or collective well-being [30].

Actions based on a system of beliefs, values, and traditions, have led the individual to adapt, persist, and transform the environment, being able to contain the disturbances or crisis. Indigenous peoples have inhabited the planet for millennia; their worldview and the historical persistence of that worldview are the sources of their belief systems, values, and traditions. These systems have interacted with the environment in a balanced way, which has allowed indigenous groups to acquire a broad knowledge of their environment for millennia. According to Marston [47] the resilience approach can help explain how and why social change occurs within an environment. Using this logic, Stojanovic et al. [48] highlight the visibility of the social component of socioecological systems, emphasizing cultural identity. According to Fernandez-Gimenez et al. [49] in Mongolia in the context of a socioecological system, the relevance of the cultural aspect in the configuration of the system was shown. 
The indigenous peoples adopt and respect their informal institutions, these rules have allowed a balance with their environment. For example, surviving disease or climate change. In times of pandemic, the tracking and understanding of the broad ancestral knowledge of indigenous groups is necessary. In this study, a case study is analyzed in detail to show the potential of institutional resilience towards one sector: food. However, on this basis, we try to extend the analysis to most of the world's indigenous peoples, using a broad review of the literature to track their informal institutions. These steps will lead us to identify their institutional resilience through the response strategies that each group of indigenous peoples in the world is deploying in the face of the COVID-19 pandemic.

\section{Indigenous Peoples, the First Resilient Societies on Earth}

For 250 years the world has been exposed to a dynamic of socioeconomic change. That level of change has led to the fourth industrial revolution [50,51]. We do not know if this social acceleration [7] is for good or for bad, what we do know is that societal attributes have been configured and adapted over time, the current global society is immersed in an advancing social metabolism $[1,4,6]$ that sees natural resources as inexhaustible. The COVID-19 pandemic is reconfiguring the world, we are seeing it with the global food system [52]. The tensions caused by the health crisis are testing the resilience of global society. We will understand the resilience of global society in the context of socioeconomic changes (e.g., population, market, trade, globalization, culture, consumption, food) to the challenge of the health crisis caused by the COVID-19 pandemic.

Perhaps, it is time to look at other experiences, forgotten or ignored like the one that the indigenous peoples of the world can offer us. According to Kirmayer et al. [53] the resilience of indigenous peoples is not being adequately recognized, the findings in the health sector from an ecological perspective are relevant. Other studies show the importance of indigenous peoples' resilience and the relevance that indigenous people give to their relationship with their environment [54]. Previous approaches can lead to the identification of elements that drive a wellbeing that impacts on global society.

The recognition of indigenous peoples as the first resilient societies on the planet has been raised from the earliest evidence with indigenous Australians and Africans. According to Nagle et al. [55], the indigenous people of Australia are one of the most resilient cultures on the planet, with evidence indicating that their ancestors arrived on the ancient continent of Sahul (present-day New Guinea and Australia) 55,000 years ago. The study by Rasmussen et al. [56] confirms that indigenous Australians were the first inhabitants of the continent. Other studies show the indigenous people of the African continent to be the oldest on the planet $\sim 100,000$ years ago [57], as well as the resilience processes that these indigenous populations undertook in the face of events such as infectious diseases, climatic conditions and food systems [58]. The availability of ancient genomes from Africa provides ancient insights into population size, dynamics of the processes that affected populations and their genetic risk of disease [59].

\section{Methods}

The qualitative approach was used to achieve the objective of the study. The development of the research had two parts; the first where the research technique was applied: case study. The case study was carried out in the indigenous territory of Huehuetla in the north of the State of Puebla in Mexico in the years 2017-2018. In the second part, in July 2020 a theoretical investigation was carried out where through a detailed literature review the required information was completed. The review was conducted through ISI Web of Science (WoS) considering the key words: indigenous* pandemic* COVID-19* resilience* institutional resilience* resilient society*. The scope of the review was local, national, and global. 


\subsection{Totonac Indigenous People}

The Totonac people speak language variants belonging to the Totonac-Tepehua language family. The live along the coastal plain of the state of Veracruz and in the northern mountains of Puebla (Mexico), where a mountainous landscape predominates. The total population reaches 438,756 inhabitants [60]. In a migration process that happened 2500 years ago, the Totonacs arrived in the central valleys of Mexico (Puebla, Tlaxcala, and Veracruz). The Totonacs were dominated by the Triple Alliance (this alliance was formed by the Mexica Empire and other territories to subdue the small groups existing in ancient Mexico), subject to strong tributes and the repression of their insurrections. In order to remove the Mexica yoke, this group supported the Spaniards in the conquest of Mexico (in the year 1519); but in return they imposed a new religion and strong services. The spread of disease devastated the native population by $90 \%$. Their relative isolation (mountainous landscape) allowed them to reorganize their cultural systems in autonomous ways in the face of Spanish domination; sometimes they achieved negotiations, sometimes they faced genocide [60].

The belief system of the Totonacs is syncretic; there is a combination of symbols and signs reworked into myths, rituals, or ceremonies whose origin is found in the Mesoamerican indigenous culture and aspects of Christianity. The Catholicism of the Totonac Indians combined elements from both traditions to create their own religiosity; this emphasizes the existence of sacred beings that have dominion over particular aspects and environments of the world, such as churches, caves or hills [61].

\subsection{Setting and Participants}

This study was conducted in the Huehuetla municipality of Puebla State in Mexico, covering 9 of the 12 communities: Chilocoyo del Carmen, Huehuetla, Chilocoyo de Guadalupe, Lipuntahuaca, Putaxcat, Xonalpu, Francisco I. Madero, Putlunichuchut, and Ozelonacaxtla. The 12 communities that make up the territory of Huehuetla share a system of beliefs, values, and traditions. As part of the academic staff of the Intercultural University of Puebla State in Mexico, the university must have a positive impact on the surrounding territories, one of these territories is the municipality of Huehuetla. On a personal level, I was interested in the Totonac ethnic group because of its cultural richness, an ideal condition for exploring institutional resilience. For these reasons, this municipality was selected to explore institutional resilience. Figure 1 shows the theoretical model that the study followed.

The municipality of Huehuetla is mostly indigenous with a population of 15,689 inhabitants. More than $89 \%$ of the total population speaks one indigenous language. The percentage of the population living in poverty is $46 \%$, this percentage is higher than the Mexican national average (43.6\%) [62]. In Huehuetla, a mountain-type land type is predominating; the climate (Köepen) is (A) C (fm), i.e., humid semi-warm of group C; the average annual temperature is greater than $18^{\circ} \mathrm{C}$; the temperature of the coldest month is less than $18{ }^{\circ} \mathrm{C}$, and the temperature of the hottest month is greater than $22{ }^{\circ} \mathrm{C}$. The municipality is divided administratively into 12 localities: (1) 5 de Mayo (1893 inhabitants), (2) Leacaman (1897), (3) Xonalpu (2100), (4) Putlunichuchut (1321), (5) Kuwik Chuchut (754), (6) Huehuetla (2065), (7) Chilocoyo del Carmen (954), (8) Francisco I. Madero (664), (9) Lipuntahuaca (1484), (10) San Juan Ozelonacaxtla (1326), (11) Putaxcat (890), and (12) Chilocoyo Guadalupe (341) [62].

For this study, the territory is a social construction, shaped by the different cultural expressions of its people. This approach recognizes that the territory in its formation is delineated by the collective identity of the indigenous group that inhabits it. According to Broda [63], indigenous food systems have been sustained from 2500 years ago until today. This explains why the cultural expressions of an indigenous people persist in the territory and with the passage of modernity they adapt to the dynamics of changes (e.g., social, environmental, economic). In this territory, the Totonac indigenous communities face adverse scenarios (e.g., disputes over territory and its natural resources: water, land, 
forests, and minerals). The elements that play an important role in the territory are not only endogenous but also exogenous. The Totonac people interact with government agencies at different levels: local, regional, and national (e.g., the National Commission for the Development of Indigenous Peoples or SADER), which impose support programs without considering their participation and needs. This reality is lived by the Totonac indigenous people, but they have adapted and taken advantage of the opportunities derived from poorly formulated public policies.

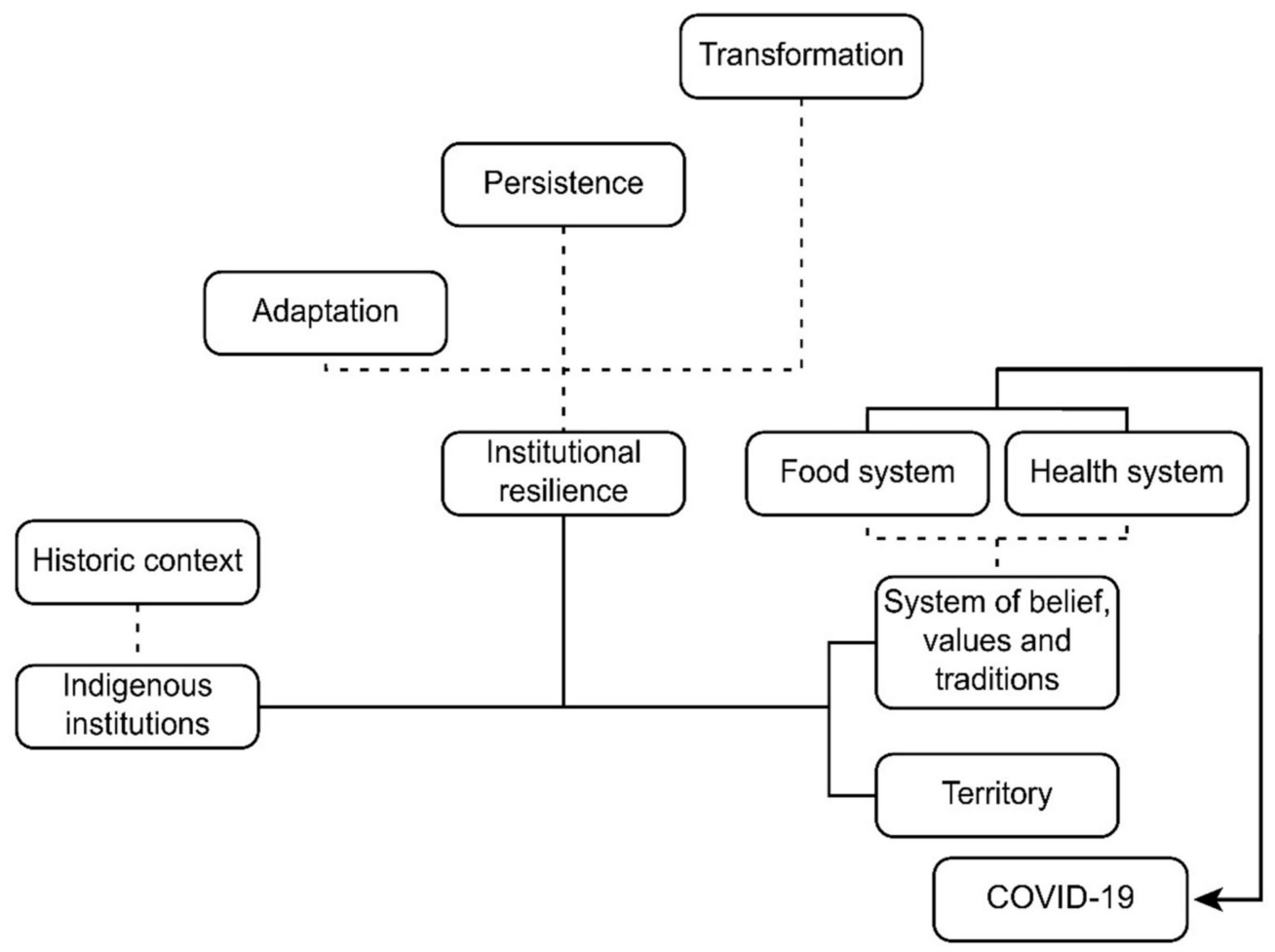

Figure 1. Theoretical model of the study.

\subsection{Qualitative Interviews, Research Limitations and Its Implications}

The case study was conducted with a qualitative approach based on two research techniques: semistructured interviews and participant observation. The application of the techniques was carried out in two phases with different temporalities.

In the first phase, 60 semistructured interviews were conducted in August 2017 in five communities in the municipality of Huehuetla: Chilocoyo del Carmen $n=8$, Huehuetla $n=14$, Chilocoyo de Guadalupe $n=8$, Lipuntahuaca $n=15$, and Putaxcat $n=15$. The questions in the initial or exploratory phase were type of productive activity in the territory, the teaching process in the productive activity, commercialization, traditions in the territory, and the relationships between productive activities and traditions and norms of coexistence within the community. In the participant observation, visits were made to the aforementioned communities to learn about their culture and its different expressions and how their cultural elements affect their food system.

In the second phase, 13 semistructured interviews with key informants were carried out in March 2018 in the communities of Putaxcat $n=2$, Xonalpu $n=4$, Francisco I. Madero $n=3$, Putlunichuchut $n=2$, and Ozelonacaxtla $n=2$. The questions in the final phase focused on the attributes of the food system and their relationship with the traditions. The interviews and participant observations were carried out with indigenous Totonacs from different localities in the municipality of Huehuetla, both women and men belonging to the ethnic group. Figure 2 shows the process of interviewing and participant observation of indigenous Totonacs in the municipality of Huehuetla. 

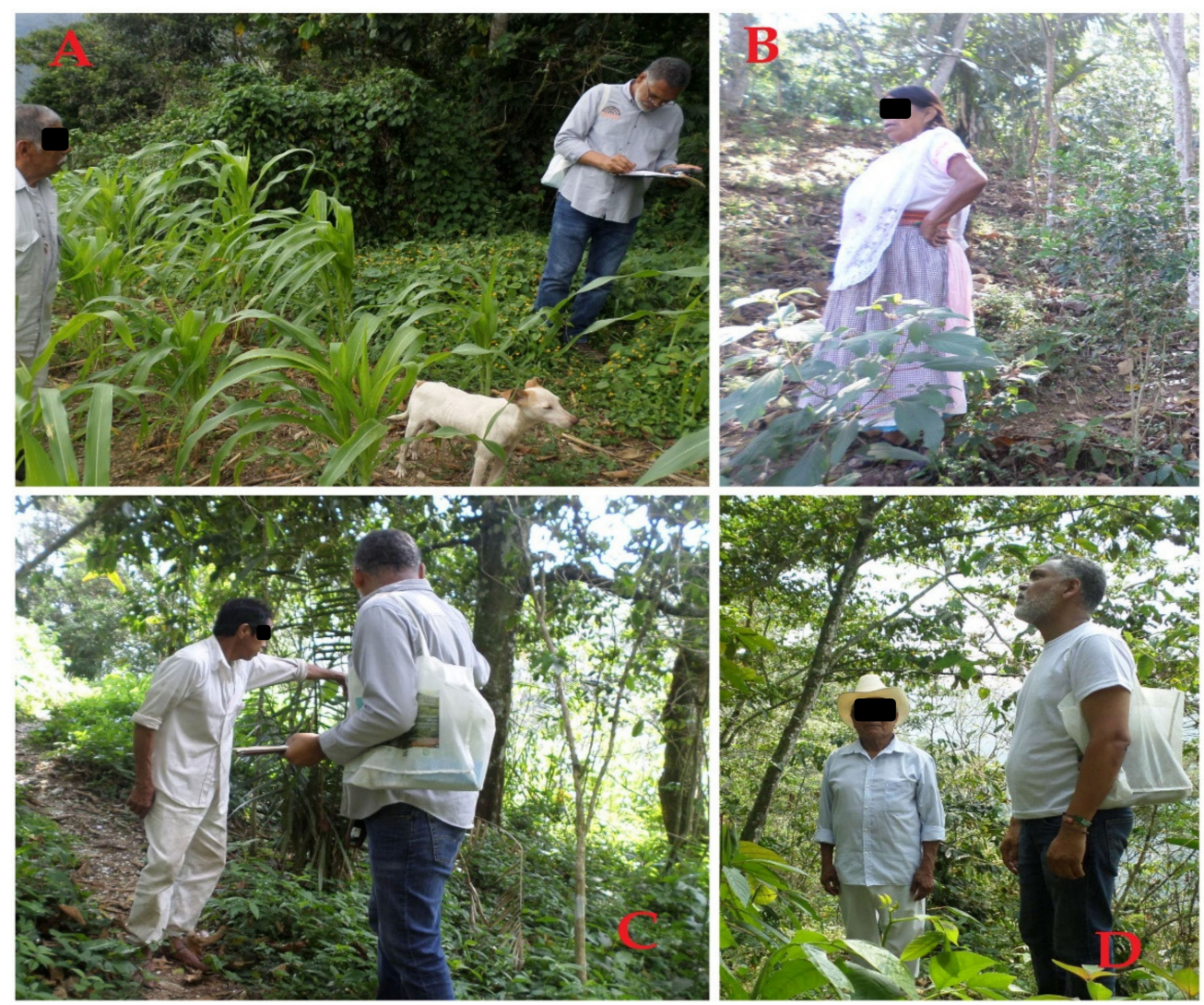

Figure 2. Interviews and participant observation in Huehuetla. (A) Community of Francisco I. Madero and (B-D) community of Putlunichuchut.

The study was nonprobabilistic, and the sample was obtained using the snowball method [64], in which the individuals selected initially helped identify other individuals with the desired characteristics.

During the fieldwork, difficulties were encountered in accessing information about the Totonac indigenous people because a low percentage spoke Spanish. Therefore, it was necessary to hire a Totonac guide who was fluent in Spanish. In addition, some resistance was perceived in the course of the interviews, but the guide helped in understanding the belief system, values, and traditions associated with their food system. An important aspect of the study was access to their plantation. The territory of Huehuetla and its communities are formed by a network of trails or improvised roads that only the Totonac indigenous know. In several cases, it was necessary to request the support of the Justice of the Peace in each community so that we could contact the Totonacs who have a plantation and who were willing to take us to see it. In some cases, the location of the plantation was different from the place where they lived. The limitations that emerged during the fieldwork were overcome due to the support of the guide, which was necessary to examine the different contexts in which the elements of the Totonac worldview are inserted.

\section{Knowing the Value of Indigenous Ancestral Knowledge: Case Study}

This section analyzes the case study and puts into context the ancestral knowledge and responses of the Totonacs to the COVID-19 pandemic through their food system. The mobilization of ancestral Totonac knowledge was observed through their food system that unites syncretic elements and agricultural practices. These elements have historically emerged from their informal institutions and have been reproduced since ancient times due to their beliefs, values and traditions.

Indigenous knowledge begins with observation and experimentation with their immediate environment, the worldview enters as an element of mediation in the interrelation- 
ships that establish the ethnic group with nature, these relationships have been established since ancient times and are inscribed in the ethnic memory and transferred by generations through informal institutions. According to UN [8], traditional knowledge is a common good that can be expressed in different ways (e.g., stories, songs, beliefs, rules, agricultural practices) and how we can apply that knowledge. In this logic, some authors argue that the specificity of indigenous knowledge prevents its application in different cultural contexts $[65,66]$. These authors do not present solid evidence about their position, the indigenous knowledge due to its attributes (observation and experimentation) adapts and transforms in different cultural contexts. The presented case study shows this process of co-evolution.

The Totonac food system covers an area between 1000 and $5000 \mathrm{~m}^{2}$ where native plant species are established and others are cultivated, such as coffee. According to Ellison [67] the Totonac plantation is characterized as a "large cultivated ecosystem". As part of the shade cultivation strategy, different species of trees are conserved, both to protect the coffee from sun damage and to produce organic fertilizer through leaf fall and nitrogen fixation (e.g., Chalahuites-Inga spp.). Sometimes, shade cultivation is combined with polyculture, which includes plants such as Citrus sinensis, Musa spp. or Pouteria sapota. It is important to mention that coffee was introduced to the plantation less than a century ago, joining the Totonac food system. The configuration of the Totonac food system is related to the different ecological levels of the region. Numerous species of plants are integrated; medicinal plants, edible plants (quelites), both in the upper and lower layers of the vegetation. These practices lead to a process of domestication of the plants.

This form of polyculture has an important socioeconomic role since it constitutes a space in which the Totonac family can satisfy several of its reproduction needs. According to Ellison [67] within the strategies of natural resource management of the families, the food system also functionally replaces the forest as a source and refuge of useful plants (medicinal and edible). The management of the Totonac food system is integrated into their system of beliefs, values, and traditions.

Due to the characteristics of the Totonac food system, the health of the Totonac people is not managed in isolation, as traditional medicine is based on the food system through traditional plants. In this logic, medicinal plants act on two fronts: as a preventive factor and as a healing factor. The COVID-19 pandemic has been successfully fought due to this logic. The theoretical model of the study (Figure 1) shows the interrelated food system and health system. The strategy devised by the Totonac ethnic group does not confront the current health crisis by a conjuncture but is a response devised since ancestral times.

\section{Results}

\section{Description of the Elements Shaping Institutional Resilience}

The analysis of the case study allowed us to understand the structure of the system of beliefs, values and traditions held by the Totonac indigenous people (Table 1). The Totonac worldview is reflected in their food system. The agronomic management that the Totonacs give to their wild (medicinal or edible plants) and cultivated (coffee, pepper, maize) crops displays a broad knowledge of the agro-ecological conditions of their territory, this knowledge is accompanied by a syncretism that has been historically constructed. The indigenous people interviewed $(100 \%)$ in the nine communities confirmed that the system of beliefs, values and traditions are fundamental to their food system.

According to the Totonac worldview, the territory is not only a provider of natural resources but also is inhabited by different beings with whom humans have mutually supportive relationships, called the owners or lords. The owners or gentlemen are deities who are considered by the Totonacs to be non-human beings in charge of protecting different areas of the territory. The owners of the mountain, water, stones, earth, and fire are recognized. Here, several Totonacs (90\%) mentioned having felt the presence of some of the deities, in particular, the deity of the mountain or owner of the mountain known among the Totonacs as Kiwikgolo. 
Table 1. Particularities of indigenous Totonac communities and their systems of beliefs, values and traditions.

\begin{tabular}{|c|c|c|c|c|}
\hline $\begin{array}{l}\text { Community/System of Beliefs, } \\
\text { Values and Traditions }\end{array}$ & $\begin{array}{c}\text { Interviews } \\
n\end{array}$ & $\begin{array}{l}\text { COVID-19 Response } \\
\text { Strategy }\end{array}$ & $\begin{array}{l}\text { Institutional } \\
\text { Resilience }\end{array}$ & $\begin{array}{l}\text { Participant } \\
\text { Observation }\end{array}$ \\
\hline \multicolumn{5}{|c|}{ Belief } \\
\hline $\begin{array}{l}\text { Putlunichuchut } \\
\text { S. J. Ozelonacaxtla } \\
\text { Francisco I. Maduro } \\
\text { Xonalpu } \\
\text { Chilocoyo del Carmen } \\
\text { Chilocoyo de Guadalupe } \\
\text { Huehuetla } \\
\text { Lipuntahuaca } \\
\text { Putaxcat }\end{array}$ & $\begin{array}{c}2 \\
2 \\
3 \\
4 \\
8 \\
8 \\
14 \\
15 \\
17 \\
\end{array}$ & $\begin{array}{l}\text { In these communities, the } \\
\text { synergy between the } \\
\text { Catholic religion and the } \\
\text { deities that form part of } \\
\text { their worldview } \\
\text { constitutes a strategy for } \\
\text { managing their food } \\
\text { system. }\end{array}$ & $\begin{array}{l}\text { These beliefs take } \\
\text { shape in a post-Spanish } \\
\text { conquest context that } \\
\text { has continued to the } \\
\text { present day. }\end{array}$ & $\begin{array}{l}\text { The fieldwork } \\
\text { confirmed the ethnic } \\
\text { syncretism in the study } \\
\text { communities associated } \\
\text { with their agricultural } \\
\text { practices. }\end{array}$ \\
\hline \multicolumn{5}{|c|}{ Values } \\
\hline $\begin{array}{l}\text { Putlunichuchut } \\
\text { S. J. Ozelonacaxtla } \\
\text { Francisco I. Maduro } \\
\text { Xonalpu } \\
\text { Chilocoyo del Carmen } \\
\text { Chilocoyo de Guadalupe } \\
\text { Huehuetla } \\
\text { Lipuntahuaca } \\
\text { Putaxcat }\end{array}$ & $\begin{array}{c}2 \\
2 \\
3 \\
4 \\
8 \\
8 \\
14 \\
15 \\
17\end{array}$ & $\begin{array}{l}\text { In each of the study } \\
\text { communities, the } \\
\text { transmission of ancestral } \\
\text { knowledge from father to } \\
\text { son is decisive, the value } \\
\text { of respect for nature } \\
\text { reinforces the idea of the } \\
\text { use of medicinal plants. }\end{array}$ & $\begin{array}{l}\text { The transmission of } \\
\text { ancestral knowledge is } \\
\text { a legacy from ancient } \\
\text { times and is the key to } \\
\text { institutional resilience. }\end{array}$ & $\begin{array}{l}\text { The human-nature } \\
\text { relationship is } \\
\text { mediated by respect. In } \\
\text { all communities, deities } \\
\text { are important in this } \\
\text { mediation. }\end{array}$ \\
\hline \multicolumn{5}{|c|}{ Traditions } \\
\hline $\begin{array}{l}\text { Putlunichuchut } \\
\text { S. J. Ozelonacaxtla } \\
\text { Francisco I. Maduro } \\
\text { Xonalpu } \\
\text { Chilocoyo del Carmen } \\
\text { Chilocoyo de Guadalupe } \\
\text { Huehuetla } \\
\text { Lipuntahuaca } \\
\text { Putaxcat }\end{array}$ & $\begin{array}{c}2 \\
2 \\
3 \\
4 \\
8 \\
8 \\
14 \\
15 \\
17\end{array}$ & $\begin{array}{l}\text { In these communities the } \\
\text { festivities to saints, } \\
\text { dances and handicrafts } \\
\text { are offerings to ask for } \\
\text { good harvests and } \\
\text { environmental health for } \\
\text { the space they cultivate. }\end{array}$ & $\begin{array}{l}\text { Totonac territories } \\
\text { possess a high cultural } \\
\text { richness expressed in } \\
\text { traditions, these } \\
\text { elements (e.g., dances, } \\
\text { offerings to saints, } \\
\text { festivals) allow for the } \\
\text { persistence of } \\
\text { institutional resilience. }\end{array}$ & $\begin{array}{l}\text { It was noted as part of } \\
\text { Totonac traditions that } \\
\text { seeds are blessed in } \\
\text { church and in their } \\
\text { homes the veneration } \\
\text { of saints for the care of } \\
\text { their crops is recurrent. }\end{array}$ \\
\hline
\end{tabular}

The realization of various festivities as offerings to saints and deities shows how the system of beliefs, values and traditions establishes a bridge between their syncretism and their plantations. This fact among the Totonacs makes the plantations healthy and give good crops. In Huehuetla, the manufacturing of decorated candles used during traditional festivals and dances is important. The recognized holidays and traditions are the Patronal Feast of San Salvador that is celebrated on 6 August and the feast of the Virgin of the Nativity that is celebrated on 8 September. Other festivals include The Divine Child Jesus, the feast on 15 November to the Virgin of the Tile in Xonalpu, The Virgin of Socorro, and The Virgin of Guadalupe. Performed at these festivities are the dances of Los Negritos, Los Quetzales, Huehues, Los Toreros de San Miguelito, Santiagueros, Moros, and Voladores. From the 12th to the 20th of December, the population venerates first the Virgin of Guadalupe and then the Reyna del Café. We see a local food system that shows not only the existence of consumption patterns, it integrates a system of beliefs, values and traditions that has developed through historical changes. During the interviews, the Totonacs $(100 \%)$ emphasized the relevance of the festivities in honor of their saints (e.g., Virgin of Guadalupe or Coffee Queen, Virgin of Socorro).

Participant observation is a valuable research technique, during fieldwork I attended several festivities and traditional dances in offerings to saints and deities, in several communities it was observed how the indigenous people carried agricultural products such as coffee or maize. 
The analysis suggests that indigenous populations in other territories may have a similar behavioral structure in the context of systems of beliefs, values and traditions. These relationships are important for the survival of indigenous peoples and govern the permanence of their informal institutions, which are the basis of their institutional resilience. To support these assertions, the analysis of the literature review made it possible to see how various indigenous peoples around the world, through the deployment of coping strategies, face COVID-19. One of the most recurrent coping strategies among the world's indigenous peoples are food systems and traditional health systems. This dialectic between the aforementioned systems is due to their complementarity, which has been useful in the challenge of the COVID-19 pandemic (e.g., several of the medicinal plants are also used as edible plants).

\section{Discussion}

\subsection{Totonac Institutional Resilience against COVID-19}

For the Totonac people the food and health systems are integrated, the space that their plantations form not only provides them with food but also with the medicinal plants for their well-being and health. The ancestral knowledge described for the Totonac food system has been put into practice to confront the threat of the COVID-19 pandemic. The indigenous peoples of the region due to confinement are using their medicinal plants, rescued ancestral agricultural practices, have limited their agricultural production only for self-consumption, generating strategies for their food security. The indigenous peoples of the region, custodians of vast ancestral knowledge, have resorted to the use of affordable plants that were not known by current generations. The strength of their institutional resilience provided the basis for establishing a food security strategy. Before the health crisis, they knew that strengthening the immune system is essential to face COVID-19. While focused on one case study within an indigenous culture, the development of a nomothetic framework may prove useful in other geographic and developmental contexts [68].

Governance in indigenous territories allows for the emergence of collective responses and decision-making in relation to particular challenges [69]. Beliefs, values, and traditions are woven into the governance process when faced with critical challenges [30]. These processes and practices harness the creative and innovative potential of culture for the implementation of adaptation and transformation possibilities [69,70]. Indigenous peoples' traditional health systems are complex and structured in their content and internal logic [71,72]. They are characterized by a combination of practices and knowledge about the human body in synergy with nature and deities [73]. Many indigenous families address diseases with a variety of approaches and practices, using traditional or Western medicine, or a combination of both [8]. Not only do the Totonacs have a robust food system, but they also combine this knowledge with traditional health practices in the face of the challenge of the COVID-19 pandemic.

\subsection{The Indigenous Peoples of the World in the Face of the COVID-19 Pandemic: A Response from Their Institutional Resilience}

Since the World Health Organization declared COVID-19 a pandemic on 11 March 2020, the infection has spread rapidly around the world, with 168 million people infected and 3.5 million dead by 28 May 2021 [17]. Similar coronavirus outbreaks have occurred in the past [74].

However, the current coronavirus outbreak (COVID-19) looks more lethal, a trend shown in Africa, Europe and Latin America with cases in the South Africa, UK and Brazil [15,75-78].

The large metropolises such as Paris, New York, London, Mexico City, Madrid, Sao Paolo, and other megalopolises have been severely affected, currently facing re-emergence of the COVID-19. In the countries of the world with indigenous peoples the situation is no different, but these peoples have shown resistance to the COVID-19. Figure 3 shows some examples of the institutional resilience capacity of the world's indigenous peoples. 


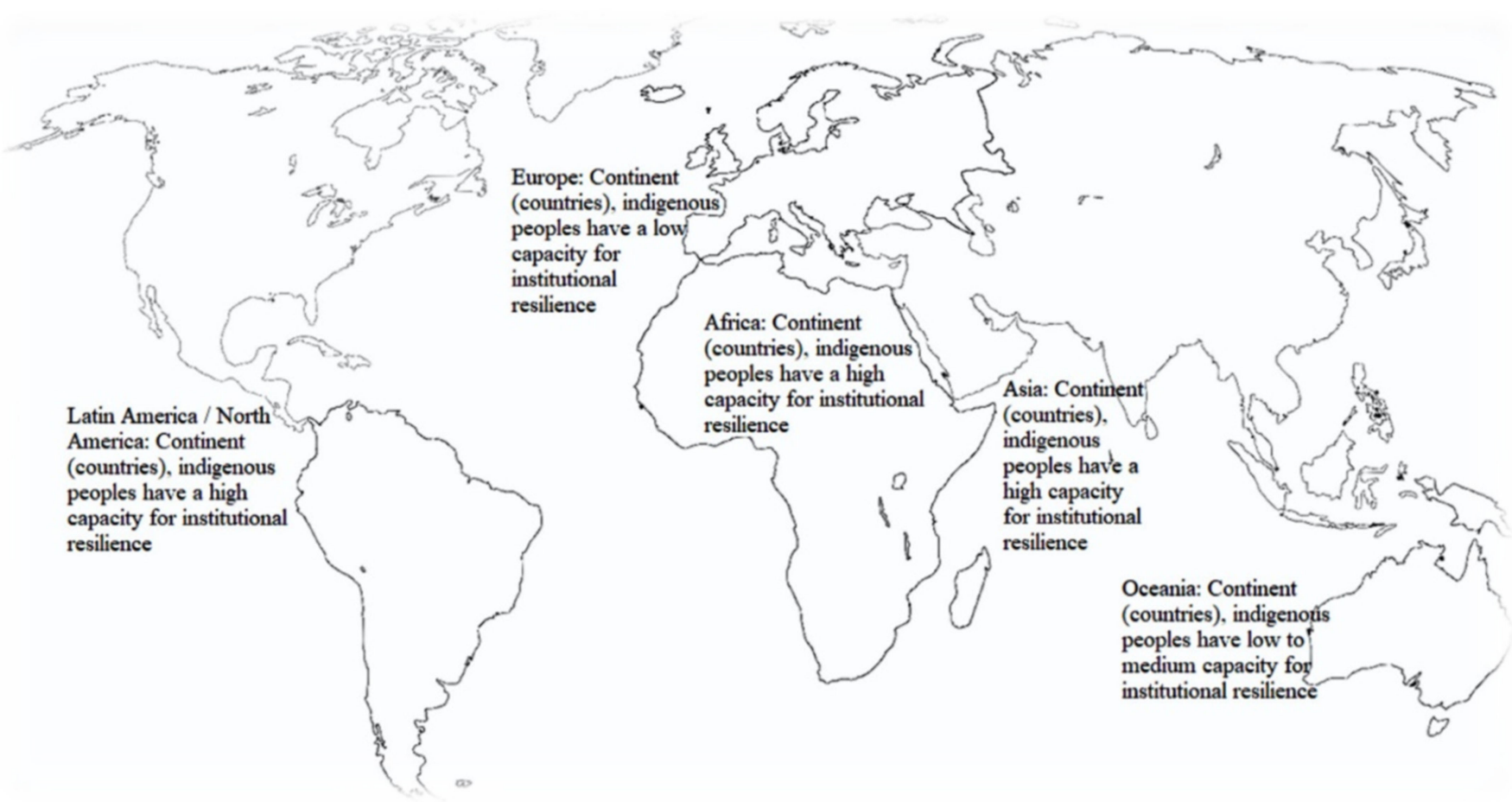

Figure 3. Institutional resilience capacity global. Source: own elaboration based on the information of [11,79].

The world's indigenous peoples are currently the subject of debate about their role in the environment and in global society [17,80-83] this fact has prevented accurate information on their population dynamics, data on the effects of the COVID-19 pandemic on indigenous peoples is limited. The available data comes from international organizations whose relationship with their indigenous peoples is poor, with feedback from secondary sources [84]. In this context, we analyze the available data on the documented cases of indigenous peoples around the world who have been affected by COVID-19. Countries with affected indigenous populations are noted and some examples are given. However, careful interpretation is required as the quality of data and testing capacity varies between countries and regions.

\subsubsection{Africa}

The African continent has many indigenous peoples, the countries that make up the continent are vulnerable because African countries have a poor health system (lack of equipment, lack of funding, insufficient training for health workers and ineffective data transmission) that does not adequately address the pandemic [85]. Africa has invested in preparedness and response activities aimed at various outbreaks on the continent (e.g., ebola virus, lassa fever, polio, tuberculosis, or human immunodeficiency virus). This expertise has been rapidly adapted to COVID-19 [86]. Africa had its first case of COVID-19 in Egypt on 14 February 2020, and in sub-Saharan Africa, the first case was reported in Nigeria on 27 February 2020 [87]. According to Ozili [88] the increase in cases affected social cohesion, especially in North African countries that share similar cultural values.

Some indigenous peoples in Africa are being affected by the COVID-19 pandemic because of the failure of peoples and cities to comply with health measures. However, many indigenous peoples have deployed strategies based on their traditional knowledge that have enabled them to cope with the pandemic [11] (Table 2). 
Table 2. African countries with indigenous populations and their strategies deployed in the face of COVID-19.

\begin{tabular}{|c|c|c|c|}
\hline Country & $\begin{array}{l}\text { Total Confirmed Cases of } \\
\text { COVID-19 in the Country [11] }\end{array}$ & $\begin{array}{l}\text { Indigenous Population* } \\
\text { (Example) }\end{array}$ & $\begin{array}{l}\text { Indigenous Strategies to Face } \\
\text { COVID-19 in the Context of } \\
\text { Institutional Resilience }\end{array}$ \\
\hline Algeria & 117,304 & Amazigh & System of beliefs, values, and traditions \\
\hline Benin & 7313 & Goun & Knowledge of ancestral medicine \\
\hline Botswana & 40,878 & Basarwa & System of beliefs, values, and traditions \\
\hline Burkina Faso & 12,774 & Gourounsi & $\begin{array}{l}\text { Food system and knowledge of } \\
\text { ancestral medicine }\end{array}$ \\
\hline Burundi & 2842 & Hutu & Knowledge of ancestral medicine \\
\hline Cameroon & 53,920 & Bakola & Food system \\
\hline $\begin{array}{l}\text { Central African } \\
\text { Republic }\end{array}$ & 5245 & Pygmies & Knowledge of ancestral medicine \\
\hline Chad & 4552 & Toubou & Food system; adaptation in desert areas \\
\hline Equatorial Guinea & 7008 & Bubi & System of beliefs, values, and traditions \\
\hline Eritrea & 3308 & Afar & Food system \\
\hline Ethiopia & 208,961 & Konso & Knowledge of ancestral medicine \\
\hline Gabon & 19,550 & Pygmies & Knowledge of ancestral medicine \\
\hline Israel & 833,269 & Bedouins & Food system; adaptation in desert areas \\
\hline Kenya & 135,042 & Ogiek & $\begin{array}{l}\text { Food system and knowledge of } \\
\text { ancestral medicine }\end{array}$ \\
\hline Libya & 159,980 & Amazigh & System of beliefs, values, and traditions \\
\hline Mali & 10,199 & Songhay & System of beliefs, values, and traditions \\
\hline Morocco & 496,676 & Berber & Knowledge of ancestral medicine \\
\hline Namibia & 44,374 & San & Food system \\
\hline Niger & 5026 & Okon Aku & Knowledge of ancestral medicine \\
\hline Republic of the Congo & 28,198 & Pygmies & Knowledge of ancestral medicine \\
\hline Rwanda & 21,918 & Tutsi & System of beliefs, values, and traditions \\
\hline South Africa & $1,549,451$ & Xhosa & Knowledge of ancestral medicine \\
\hline Tanzania & 509 & Bantu & Knowledge of ancestral medicine \\
\hline Tunisia & 255,308 & Amazigh & System of beliefs, values, and traditions \\
\hline Uganda & 40,889 & Batwa & Knowledge of ancestral medicine \\
\hline Zimbabwe & 36,896 & Tshwa & Knowledge of ancestral medicine \\
\hline
\end{tabular}

* Note: the construction of the table was carried out based on contributions from various authors and reports from international organizations. Sources: [11,89-107].

The indigenous populations of Africa have a rich culture that has enabled them to cope with the COVID-19 pandemic [108]. The intervention process in some African countries with indigenous peoples has been fragmented, causing countries such as South Africa, with confirmed cases of COVID-19 to increase [109]; in the rest of the countries of the continent deficiencies in the health system have been a determining factor in the increase of COVID-19 [110]. The emergence of a new variant has increased the number of deaths in southern Africa [77], testing the institutional resilience of indigenous peoples in this region.

In Table 2, we can see that countries with indigenous populations such as Burundi, Eritrea, or Tanzania do not have more than 4000 confirmed cases of COVID-19. According to Villalonga-Morales [111] four factors (age pyramids, environmental temperature, social and political) have allowed a slowdown in the pandemic in Africa. Alternatively, their infectious disease capacity is also considered. According to Rotimi et al. [58] the resilience of Africans to pandemics has been widely evidenced due to their genomes. Indigenous populations and African populations in general, due to a high allele frequency, have survival advantages in infectious diseases.

\subsubsection{Asia}

The COVID-19 pandemic began in the Asian region, China, which eventually spread to the rest of China and subsequently throughout the continent [112]. As of 20 April 2020, the most affected Asian countries after China were Turkey, Iran, India, Israel, Saudi Arabia, Japan, South Korea [113]. The total number of confirmed cases of COVID-19 in countries with indigenous populations in the Asian region decreased (Table 3). 
Table 3. Asian countries with indigenous populations and their strategies deployed in the face of COVID-19.

\begin{tabular}{|c|c|c|c|}
\hline Country & $\begin{array}{l}\text { Total Confirmed Cases of } \\
\text { COVID-19 in the Country [11] }\end{array}$ & $\begin{array}{l}\text { Indigenous Population* } \\
\text { (Example) }\end{array}$ & $\begin{array}{l}\text { Indigenous Strategies to Face } \\
\text { COVID-19 in the Context of } \\
\text { Institutional Resilience }\end{array}$ \\
\hline Bangladesh & 617,764 & Chakma & System of beliefs, values, and traditions \\
\hline Cambodia & 2477 & Bunong & Knowledge of ancestral medicine \\
\hline China & 102,790 & $\begin{array}{l}\text { Paiwan and Rukai } \\
\text { (Taiwan) }\end{array}$ & System of beliefs, values, and traditions \\
\hline India & $12,303,131$ & Khasi & Food system as support health system \\
\hline Indonesia & $1,517,854$ & Batak & $\begin{array}{l}\text { Indigenous governance and system of } \\
\text { beliefs, values, and traditions }\end{array}$ \\
\hline Kazakhstan & 299,626 & Kazakhs & System of beliefs, values, and traditions \\
\hline Kyrgyzstan & 88,700 & Uyghurs & System of beliefs, values, and traditions \\
\hline Japan & 477,458 & Ryūkyūs & System of beliefs, values, and traditions \\
\hline Laos PDR & 49 & Hmong & System of beliefs, values, and traditions \\
\hline Malaysia & 346,678 & Batek & $\begin{array}{l}\text { Knowledge of ancestral medicine and } \\
\text { closed territory }\end{array}$ \\
\hline Myanmar & 142,466 & Müün & Knowledge of ancestral medicine \\
\hline Nauru & 0 & Nauruans & Food system \\
\hline Nepal & 277,461 & Brahmin-Chhetri & $\begin{array}{l}\text { Food system and knowledge of } \\
\text { ancestral medicine }\end{array}$ \\
\hline Sri Lanka & 92,917 & Vedda & Food system \\
\hline Philippines & 756,199 & Mamanwa & $\begin{array}{l}\text { Food system and the role of community } \\
\text { elders as local hazard forecasters }\end{array}$ \\
\hline Tajikistan & 13,714 & Uzbeks & System of beliefs, values, and traditions \\
\hline Thailand & 28,947 & Khmer & $\begin{array}{l}\text { Food system and system of beliefs, } \\
\text { values, and traditions }\end{array}$ \\
\hline Timor-Leste & 643 & Mambai & Food system \\
\hline Turkmenistan & 0 & Russians & System of beliefs, values, and traditions \\
\hline Uzbekistan & 83,239 & Tajiks & System of beliefs, values, and traditions \\
\hline Vanuatu & 3 & Part Ni-Vanuatu & Food system \\
\hline Vietnam & 2617 & Yao & System of beliefs, values, and traditions \\
\hline
\end{tabular}

* Note: the construction of the table was carried out based on contributions from various authors. Sources: [114-128].

The dynamics of Asian countries with indigenous populations show few cases confirmed by COVID-19, except for India, which has more than 12 million confirmed cases. Countries such as Turkmenistan and Nauru do not present cases. This trend of low confirmed cases of COVID-19 is explained by the measures that these governments have adopted in the face of the pandemic and a lower proportion by the geography of some countries and the institutional resilience of their ethnic groups.

The dynamics of institutional resilience of indigenous peoples in Asia show a diversity of informal institutions based on a strong system of beliefs, values, and traditions. Among the most important strategies identified were governance, knowledge of ancestral medicine and food systems. These indigenous peoples have relied on the above-mentioned strategies to cope with the COVID-19 pandemic.

\subsubsection{Europe}

Europe was considered as the active center of COVID-19 after the situation improved in China [11]. Scenarios suggest regional growth will fall into a recession in 2020, contracting between -4.4 and $-2.8 \%$ held back by the coronavirus pandemic, and rebound subsequently to roughly 5.6 to $6.1 \%$ in 2021 as policy measures are introduced, global commodity prices gradually recover and trade strengthens [129]. The outlook faces unprecedented downside risks related to the coronavirus, with these scenario ranges reflecting large unknowns on the ultimate severity and duration of the pandemic.

Although the magnitudes are uncertain, the pandemic is certain to derail the near-term outlook by weighing on domestic demand, putting further downward pressure on commodity prices, disrupting tightly linked global and regional supply chains, reducing travel 
and tourist arrivals, and decreasing demand for exports from the region. Policymakers across the region face a difficult trade-off between the health benefits of social distancing and quarantine measures and the economic costs of these actions [130].

According to history, Europeans seem to have always had conflicting relationships with indigenous populations, first in the conquest [12] and secondly, little tolerance for their indigenous populations $[131,132]$. Currently, few European countries have indigenous peoples, among them, we mention Finland, France, Norway, Sweden, Russia. Countries that rediscover the importance of having these populations in their territories [133]. Four countries share a single indigenous people, the Sami. Evidence suggests that the Sami have inhabited their territories for some 4000 years, moving north in pursuit of the reindeer herds. The Sami people adjusted to the various ecosystems of the sub-Arctic and Arctic regions [133].

Those in the forested areas lived by hunting, fishing, and gathering as food supplies permitted in sizeable villages at key harvesting sites; this was the most common form of a Sami subsistence lifestyle. The Sami were, like other indigenous peoples, deeply spiritual, counting on various gods and spirits to guide their lives and their actions [134] (Table 4).

Table 4. European countries (continent) with indigenous populations and their strategies deployed in the face of COVID-19.

\begin{tabular}{llll}
\hline Country & $\begin{array}{l}\text { Total Confirmed Cases of } \\
\text { COVID-19 in the Country [11] }\end{array}$ & $\begin{array}{l}\text { Indigenous Population * } \\
\text { (Example) }\end{array}$ & $\begin{array}{l}\text { Indigenous Strategies to Face } \\
\text { COVID-19 in the Context of } \\
\text { Institutional Resilience }\end{array}$ \\
\hline $\begin{array}{l}\text { France (France Polynesia) } \\
\text { Finland }\end{array}$ & 18,633 & Mā'ohi & Food system \\
$\begin{array}{l}\text { Norway } \\
\text { Sweden }\end{array}$ & 78,106 & Sami & Food system and system of \\
Russia & 96,079 & & beliefs, values, and traditions \\
\hline
\end{tabular}

* Note: the construction of the table was carried out based on contributions from various authors. Sources: [11,134-138].

The indigenous Sami group is known to have a system of beliefs, values, and traditions around health [135] but there is not enough documentation to indicate its relationship with the containment strategies of the COVID-19 pandemic that have been implemented by the governments of Finland and Norway.

\subsubsection{Latin America/North America}

Until 20 April 2020, all North American countries reported COVID-19 infections [139]. The first case in North America was reported in the United States on 20 January 2020 [140]. As of 20 April 2020, the United States nationally was in the acceleration phase of the pandemic with the largest number of confirmed coronavirus cases in the world along with first ranking in the number of total deaths from the virus [141].

The COVID-19 pandemic has hit Latin America in a period of economic weakness and macroeconomic vulnerability [142]. In the decade following the global financial crisis (2010-2019), regional GDP growth fell from $6 \%$ to $0.2 \%$. As the pandemic spreads across the region, its nature as health, economic, and social crisis is increasingly evident [143]. The Latin American countries at the beginning of the COVID-19 pandemic had to adopt economic policies to mitigate the social and economic effects. These measures succeeded in increasing public resources for the health sector, protecting households, maintaining production capacity and employment, and preventing the collapse of the economic system [143,144].

The countries of Latin America/North America constitute one of the most important regions in indigenous populations, these populations are located in different territories and add a legacy as custodians of biodiversity. Many indigenous populations are using their ancestral knowledge to confront the COVID-19 pandemic. However, others, due to external interventions face a difficult situation due to COVID-19, for example, in the Yanomami indigenous peoples of Brazil, due to mining activities, they have spread COVID-19 [145]. 
According to [11,79], in areas with isolated populations care is even more urgent because these peoples are more susceptible to contagious diseases. This is the case of the Yanomami indigenous territory, which has eight registers of peoples in voluntary isolation [81]. Indigenous territories are invaded by miners. The direct effect of the invasion has been the emergence of malaria and COVID-19 [146]. From 2016 to date, the public policies of the Brazilian governments have been to dispossess indigenous lands (Table 5). The Peruvian Amazon and its indigenous populations not only face the challenge of the COVID-19 pandemic but the indigenous people of the region live in voluntary isolation, and the interventionist stance of the state endangers their survival [147]. The indigenous people of the Peruvian Amazon have extensive knowledge of the region's biodiversity and despite their apparent immunological vulnerability have remained safe. The indigenous populations affected by COVID-19 live close to or within large urban settlements that, due to the lack of basic services, are easy prey to the virus.

Table 5. Countries in Latin America and North America with indigenous populations and their strategies deployed in the face of COVID-19.

\begin{tabular}{|c|c|c|c|}
\hline Country & $\begin{array}{l}\text { Total Confirmed Cases of } \\
\text { COVID-19 in the Country [11] }\end{array}$ & $\begin{array}{l}\text { Indigenous Population* } \\
\text { (Example) }\end{array}$ & $\begin{array}{l}\text { Indigenous Strategies to Face } \\
\text { COVID-19 in the Context of } \\
\text { Institutional Resilience }\end{array}$ \\
\hline Argentina & $2,348,821$ & Wichí & $\begin{array}{l}\text { System of beliefs, values, and traditions } \\
\text { Food system and traditional }\end{array}$ \\
\hline Belize & 12,456 & Mopan & $\begin{array}{l}\text { governance system to establish border } \\
\text { control points }\end{array}$ \\
\hline Bolivia & 272,411 & Weenhayek & $\begin{array}{l}\text { System of beliefs, values, and traditions, } \\
\text { Knowledge of ancestral medicine and } \\
\text { food system }\end{array}$ \\
\hline Brazil & $12,748,747$ & Yanomami & Food system \\
\hline Canada & 982,116 & Métis & System of beliefs, values, and traditions \\
\hline Chile & $1,003,406$ & Mapuche & System of beliefs, values, and traditions \\
\hline Colombia & $2,406,377$ & Putumayo & $\begin{array}{l}\text { Food system and knowledge of } \\
\text { ancestral medicine }\end{array}$ \\
\hline Costa Rica & 216,764 & Maleku & Knowledge of ancestral medicine \\
\hline Ecuador & 330,388 & Shuar & $\begin{array}{l}\text { Traditional governance system to } \\
\text { establish border control points and } \\
\text { food system }\end{array}$ \\
\hline French Guiana & 17,132 & Arowaka/Lokono & $\begin{array}{l}\text { Traditional governance system to } \\
\text { establish border control points and } \\
\text { food system }\end{array}$ \\
\hline Greenland (Denmark) & 31 & Kalaallit & System of beliefs, values, and traditions \\
\hline Guatemala & 194,398 & Garifuna & System of beliefs, values, and traditions \\
\hline Guyana & 10,249 & Wai-Wai & System of beliefs, values, and traditions \\
\hline Honduras & 189,043 & Lenca & $\begin{array}{l}\text { Traditional governance system to } \\
\text { establish border control points }\end{array}$ \\
\hline Mexico & $2,238,887$ & Maya & Knowledge of ancestral medicine \\
\hline Nicaragua & 5326 & Miskitu & System of beliefs, values, and traditions \\
\hline Panama & 355,051 & Naso & System of beliefs, values, and traditions \\
\hline Paraguay & 214,667 & Mbya-Guarani & Knowledge of ancestral medicine \\
\hline Peru & $1,548,807$ & Asháninkas & Knowledge of ancestral medicine \\
\hline Isla de Pascua (Chile) & 5 & Rapa Nui & System of beliefs, values, and traditions \\
\hline Suriname & 9122 & Wayana & System of beliefs, values, and traditions \\
\hline United States & $30,159,557$ & Little Shell & System of beliefs, values, and traditions \\
\hline Uruguay & 105,549 & Charrua & Knowledge of ancestral medicine \\
\hline Venezuela & 160,497 & Ye'kwana & $\begin{array}{l}\text { Food system and knowledge of } \\
\text { ancestral medicine }\end{array}$ \\
\hline
\end{tabular}

* Note: the construction of the table was carried out based on contributions from various authors and reports from international organizations. Sources: $[11,79,148]$. 
As of March 2021, the state of Manaus, a state with a large indigenous population, has seen an increase in the number of deaths due to a new outbreak of the virus, the poor management of the health crisis in the Amazonian state and the emergence of a new variant of the virus [78].

The situation of Brazil's indigenous people deserves special attention. The rest of the indigenous population of this continent, who are the majority, demonstrate a robust institutional resilience, which has allowed them to cope with the COVID-19 pandemic. Some of the strategies that indigenous peoples have deployed on this continent are knowledge of ancestral medicine, the food system, and governance in their territories.

\subsubsection{Oceania}

The first confirmed case of COVID-19 in Australia occurred on 25 January 2020 [149]. Since then, 29,322 patients have been diagnosed nationally, resulting in 909 deaths as of 12 April 2021 [11]. New Zealand's case is different since the beginning of the pandemic in the country only 2227 cases have been confirmed nationally, political prevention measures have been critical to mitigating the presence of COVID-19 in the country [150,151]. Indigenous populations, such as the Māori of New Zealand, used their informal institutions, an example is restoration of its food system in an urban context [152], complementing with the official measures issued by the government for facing the COVID-19 pandemic. Other indigenous people like those of Papua New Guinea were helped by the geopolitical position of their country. The food system of the indigenous people of Papua New Guinea allows them to be relatively isolated in the context of the pandemic [153] (Table 6).

Table 6. Oceania countries with indigenous populations and their strategies deployed in the face of COVID-19.

\begin{tabular}{llll}
\hline Country & $\begin{array}{l}\text { Total Confirmed Cases of } \\
\text { COVID-19 in the Country [11] }\end{array}$ & $\begin{array}{l}\text { Indigenous Population * } \\
\text { (Example) }\end{array}$ & $\begin{array}{l}\text { Indigenous Strategies to Face } \\
\text { COVID-19 in the Context of } \\
\text { Institutional Resilience }\end{array}$ \\
\hline $\begin{array}{lll}\text { Australia } \\
\text { New Caledonia }\end{array}$ & 29,322 & Ngaliwurru & Knowledge of ancestral medicine \\
Kew Zealand & 121 & Māori & $\begin{array}{l}\text { Food system } \\
\text { Traditional governance system to } \\
\text { establish border control points }\end{array}$ \\
Papua New Guinea & 2227 & Kudjip Ownim & Food system \\
\hline
\end{tabular}

* Note: the construction of the table was carried out based on contributions from various authors. Sources: [154-156].

Several international organizations have supported the importance of the belief system, values, and traditions of indigenous peoples around the world $[10,11,79,84,146]$. The deployment of diverse strategies in response to the COVID-19 pandemic shows the relevance of ethnic social institutions, which have been historically renewed for generations configuring a robust institutional resilience. The experiences mentioned by the different indigenous groups provide the analytical tools for advocacy and public policy design aimed at preparing future scenarios before new pandemics.

\subsection{The Global Future and Some Lessons Learned}

Institutional resilience with an analytical tool has shown how tracking the informal institutions of indigenous populations can change the balance in terms of wellbeing and health. These institutions based on ancient conceptions are contained in human DNA and can provide insights into how ancestral indigenous people coped with infectious diseases [157,158].

Western hegemonic thinking has looked for answers in the wrong places. According to Sirugo et al. [159] most studies of genetic association with disease have been conducted in Europeans. This European bias has important implications for predicting disease risk in global populations. The diversity of African populations has been ignored and the few studies conducted show progress in infectious disease management [160]. 
Poor knowledge of indigenous populations prevents us from fully understanding the genetic architecture of human diseases and exacerbates health inequalities [159]. Although the analysis is limited to exploring the institutional resilience of an indigenous group in the context of food, the approach of this perspective shows how the construction and persistence of informal institutions has helped to pave the way for learning from the diverse areas (e.g., health, environment, food) that emerge from indigenous populations. There are 476 million indigenous people in the world, located in more than 90 countries, and the potential of these cultures is enormous if we consider them not only from the perspective of institutional resilience but also from the nomothetic aspect.

\section{Conclusions}

The results allow us to recognize that in the territories of Huehuetla, informal institutions play an important role in Totonac food system. The foregoing could be observed and determined by the cultural wealth of the Totonac indigenous group that is expressed in its belief system, values, and traditions, which was explained in detail in 9 of the 12 communities studied in the municipality of Huehuetla. The promotion and conservation of agro-productive strategies through dances, religious festivals, and rituals are a sign of what has been mentioned previously. The values, beliefs, and traditions in the municipality can be the vehicle for territorial transformation and the movement from a marginalized territory with unique attributes (beliefs, values, traditions, institutions) to a cultural territory with the potential to develop a regional food system.

The multiplicity of informal institutions in the Totonac indigenous group makes it possible to assert that there is a robust institutional resilience of the indigenous group and constitutes in the municipality of Huehuetla a decisive element in local development. This leads to a rethinking of local development in indigenous and rural territories where belief systems, values, and traditions are in force.

Restoring traditional knowledge in today's era can make a difference in drawing community development processes. It is important to strengthen the territories with cultural richness through the design and implementation of public policies that allow us to advance towards a recognition that these territories can offer, specifically, we point out the indigenous food systems. However, the experience described in this study not only shows its food potential but through this system interrelations are woven that did not exist before but that with the COVID-19 pandemic has emerged.

The emergence of a health crisis such as the one triggered by the COVID-19 pandemic points to the importance of indigenous food systems, these ancestrally designed systems not only emerged to provide an ethnic diet but also to respond to challenges (e.g., conquests, wars, diseases, pandemics, climate change). The literature review shows that across continents (Africa, Asia, Europe, Latin America/North America and Oceania) a significant number of indigenous peoples have based their coping strategies for COVID-19 on their food systems.

Strengthening institutional resilience should be geared towards protecting their systems of beliefs, values and traditions. The main lesson learned is that food systems are more broadly conceived than expected. The possibility of integrating the institutional resilience approach by learning from the experience of the informal institutions of the world's indigenous groups through the design of public policies should not be understood as a step backward to modernity, but rather to the possibility of improving the sustainability of the planet and human health in the face of the COVID-19 pandemic.

Funding: This research benefited from funds granted by PRODEP. Years: 2017-2018. UIEP-PTC-042.

Institutional Review Board Statement: The study was conducted according to the guidelines of the ethics of Intercultural University of Puebla State.

Informed Consent Statement: Informed consent was obtained from all subjects involved in the study.

Data Availability Statement: All data and materials have been presented in the paper. 
Acknowledgments: The author wishes to express his gratitude to the Totonac people for their hospitality during the fieldwork.

Conflicts of Interest: The author declares no conflict of interest.

\section{References}

1. Martinez-Alier, J. Social metabolism, ecological distribution conflicts, and languages of valuation. Capital. Nat. Soc. 2009, 20, 58-87. [CrossRef]

2. Ceballos, G.; García, A.; Ehrlich, P. The sixth extinction crisis loss of animal populations and species. J. Cosmol. 2010, 8, 1821-1831.

3. Ceballos, G.; Ehrlich, P.; Dirzo, R. Population losses and the sixth mass extinction. Proc. Natl. Acad. Sci. USA 2017, 114, E6089-E6096. [CrossRef]

4. Krausmann, F.; Erb, K.-H.; Gingrich, S.; Haberl, H.; Bondeau, A.; Gaube, V.; Lauk, C.; Plutzar, C.; Searchinger, T.D. Global human appropriation of net primary production doubled in the 20th century. Proc. Natl. Acad. Sci. USA 2013, 110, 10324-10329. [CrossRef]

5. Otto, I.; Wiedermann, M.; Cremades, R.; Donges, J.; Auer, C.; Lucht, W. Human agency in the Anthropocene. Ecol. Econ. 2020, 167, 106463. [CrossRef]

6. Marco, I.; Enric, R.P. Labour, nature, and exploitation: Social metabolism and inequality in a farming community in mid-19th century Catalonia. J. Agrar. Chang. 2020, 20, 408-436. [CrossRef]

7. Cristiano, J. For Sociological Precision Regarding the Concept of Social Acceleration. Estud. Sociol. 2020, 114, 829-848.

8. UN. State the World'S Indigenous Peoples; Department of Economic and Social Affairs of the United Nations Secretariat: New York, NY, USA, 2009.

9. Martinez-Cobo, J.R. Study of the Problem of Discrimination against Indigenous Populations. Volume V: Conclusions, Proposals, and Recommendations; United Nations: New York, NY, USA, 1987.

10. ILO. COVID-19 and the world of work: A focus on indigenous and tribal peoples. In Policy Brief, Work and Equality Department Gender, Equality and Diversity \& ILO/AIDS Branch; International Labour Organization: Geneva, Switzerland, 2020.

11. IWGIA. The Indigenous World 2020; The International Work Group for Indigenous Affairs (IWGIA): Copenhagen, Denmark, 2020.

12. Pringle, H. How Europeans brought sickness to the New World. Nature 2015. Available online: https://www.sciencemag.org/ news / 2015/06/how-europeans-brought-sickness-new-world (accessed on 12 December 2020).

13. Lai, C.-C.; Shih, T.-P.; Ko, W.-C.; Tang, H.-J.; Hsueh, P.-R. Severe acute respiratory syndrome coronavirus 2 (SARS-CoV-2) and coronavirus disease-2019 (COVID-19): The epidemic and the challenges. Int. J. Antimicrob. Agents 2020, 55, 105924. [CrossRef]

14. Gulati, A.; Pomeranz, C.; Qamar, Z.; Thomas, S.; Frisch, D.; George, G.; Summer, R.; DeSimone, J.; Sundaram, B.A. Comprehensive Review of Manifestations of Novel Coronaviruses in the Context of Deadly COVID-19 Global Pandemic. Am. J. Med. Sci. 2020, 360, 5-34. [CrossRef]

15. Iacobucci, G. Covid-19: New UK variant may be linked to increased death rate, early data indicate. BMJ 2021, 372, n230. [CrossRef]

16. Pappa, S.; Ntella, V.; Giannakas, T.; Giannakoulis, V.G.; Papoutsi, E.; Katsaounou, P. Prevalence of depression, anxiety, and insomnia among healthcare workers during the COVID-19 pandemic: A systematic review and meta-analysis. Brain Behav. Immun. 2020, 88, 901-907. [CrossRef]

17. WHO. Coronavirus Disease (COVID-19) Dashboard. Global Situation. 2021. Available online: https://covid19.who.int/ (accessed on 28 May 2021).

18. Hodgson, S.H.; Mansatta, K.; Mallet, G.; Harris, V.; Emary, K.; Pollard, A.J. What defines an efficacious COVID-19 vaccine? A review of the challenge assessing the clinical efficacy of vaccines against SARS-CoV-2. Lancet Infect. Dis. 2021, 21, E26-E35. [CrossRef]

19. Prü $\beta$, B.M. Current State of the First COVID-19 Vaccines. Vaccines 2021, 9, 30. [CrossRef]

20. Huang, Y.; Zhao, N. Generalized anxiety disorder, depressive symptoms, and sleep quality during COVID-19 outbreak in China: A web-based cross-sectional survey. Psychiatry Res. 2020, 288, 112954. [CrossRef] [PubMed]

21. Rajkumar, R.P. COVID-19 and mental health: A review of the existing literature. Asian J. Psychiatry 2020, 52, 102066. [CrossRef] [PubMed]

22. Kumar, A.; Somani, A. Dealing with Coronavirus anxiety and OCD. Asian J. Psychiatry 2020, 51, 102053. [CrossRef] [PubMed]

23. Seidi, P.A.; Ardebil, M.D.; Jaff, D. COVID-19 pandemic: New challenge to securing mental well-being in conflict settings. Asian J. Psychiatry 2020, 51, 102151. [CrossRef]

24. Huremovic, D. Brief history of pandemics (pandemics throughout history). Psychiatry Pandemics 2019, 7-35. [CrossRef]

25. Liu, Y.-C.; Kuo, R.-L.; Shih, S.-R. COVID-19: The first documented coronavirus pandemic in history. Biomed. J. 2020, 43, 328-333. [CrossRef]

26. Lopez, A. Cosmovisión y Pensamiento Indígena; Universidad Nacional Autonoma de México: Mexico City, México, 2012.

27. Le Saout, S.; Hoffmann, M.; Shi, Y.; Hughes, A.; Bernard, C.; Brooks, T.M. Protected areas and effective biodiversity conservation. Science 2013, 342, 803-805. [CrossRef]

28. Scott, W.; Vare, P. Learning, Environmental and Sustainable Development: A History of Ideas; Routledge: London, UK, 2020.

29. Lugo-Morin, D.R.; Garcia-Sanchez, E.; Cruz-Vazquez, R.I. Beliefs, values, and traditions: Re-thinking sustainable development using the Hñähñu example. Dev. Pract. 2019, 29, 95-102. [CrossRef] 
30. Lugo-Morin, D.R. Indigenous communities and their food systems: A contribution to the current debate. J. Ethnic Foods 2020, 7, 6. [CrossRef]

31. Lugo-Morin, D.R. Resiliencia institucional y desarrollo comunitario: Hacia la promoción de los territorios culturalmente superiores. In Sociedad Global, Crisis Ambiental y Sistemas Socio-Ecológicos; Quintana, F., Ed.; Universidad Nacional Autonoma de México: Ciudad de México, Mexico, 2019; pp. 158-173.

32. Lugo-Morin, D.R.; Frolich, L.M.; Magal-Royo, T. Relación ser humano-naturaleza: Debatiendo el desarrollo sostenible desde la Filosofía de la ciencia. Eur. Sci. J. 2015, 11, 1-12.

33. Raskin, P.; Tariq, B.; Gilberto, G.; Pablo, G.; Hammond, A.; Robert, K.; Swart, R. La Gran Transición: La Promesa y la Atracción del Futuro; CEPAL: Santiago de Chile, Chile, 2006.

34. Folke, C.; Polasky, S.; Rockstrom, J.; Galaz, V.; Westley, F.; Lamont, M.; Scheffer, M.; Österblom, H.; Carpenter, S.R.; Chapin, F.S.; et al. Our future in the Anthropocene biosphere. Ambio 2021, 50, 834-869. [CrossRef]

35. Vandebroek, I.; Pieroni, A.; Stepp, J.R.; Hanazaki, N.; Ladio, A.; Alves, R.R.N.; Picking, D.; Delgoda, R.; Maroyi, A.; van Andel, T.; et al. Reshaping the future of ethnobiology research after the COVID-19 pandemic. Nat. Plants 2020, 6, 723-730. [CrossRef]

36. Cawthorn, D.M.; Kennaugh, A.; Ferreira, S.M. The future of sustainability in the context of COVID-19. Ambio 2021, 50, 812-821. [CrossRef]

37. Boretti, A.; Rosa, L. Reasseeeing the projections of the World Water Development Report. NPJ Clean Water 2019, 2, 15. [CrossRef]

38. Lugo-Morin, D.R. Global future: Low-carbon economy or high-carbon economy? World 2021, 2, 175-193. [CrossRef]

39. IPCC. Cambio Climático 2014: Impactos, Adaptación y Vulnerabilidad-Resumen Para Responsables de Políticas. Contribución del Grupo de Trabajo II al Quinto Informe de Evaluación del Grupo Intergubernamental de Expertos Sobre el Cambio Climático; Organización Meteorológica Mundial: Ginebra, Switzerland, 2014.

40. Gunderson, L.; Holling, C.S.; Pritchard, L.; Peterson, G.D. Resilience. The Earth system: Biological and ecological dimensions of global environmental change. In Encyclopedia of Global Environmental Change; Mooney, H.A., Canadell, J.G., Eds.; Wiley: Paris, France, 2002; pp. 530-531.

41. Walker, B.; Holling, C.S.; Carpenter, S.R.; Kinzig, A. Resilience, adaptability, and transformability in social-ecological systems. Ecol. Soc. 2004, 9, 5. [CrossRef]

42. Lugo-Morin, D.R. Resiliencia Adaptativa: UN Marco Para el Diseño de Políticas Públicas; Editorial Abya Yala: Quito, Ecuador, 2015.

43. Folke, C. Resilience (Republished). Ecol. Soc. 2016, 214, 44. [CrossRef]

44. North, D.C. Institutions, Institutional Change and Economic Performance; Cambridge University Press: Cambridge, UK, 1990.

45. Schutz, A. El mundo de la Vida Cotidiana y la Actitud Natural. Las Estructuras del Mundo de la Vida; Amorrortu Editores: Buenos Aires, Argentina, 1973; pp. 25-40.

46. Navarrete, C. Institucionalismo informal: Tras las huellas de un discurso institucionalista informal. Perf. Latinoam. 2016, 24, 283-306. [CrossRef]

47. Marston, J.M. Modeling resilience and sustainability in ancient agricultural systems. J. Ethnobiol. 2015, 35, 585-605. [CrossRef]

48. Stojanovic, T.; McNae, H.; Tett, P.; Reis, J.; Smith, H.D.; Dillingham, I. The 'social' aspect of social-ecological systems: A critique of analytical frameworks and findings from a multisite study of coastal sustainability. Ecol. Soc. 2016, 2, 15. [CrossRef]

49. Fernández-Giménez, M.E.; Venable, N.H.; Angerer, J.; Fassnacht, S.R.; Reid, R.S.; Khishigbayar, J. Exploring linked ecological and cultural tipping points in Mongolia. Anthropocene 2017, 17, 46-69. [CrossRef]

50. Benedikter, R.; Fathi, K. The Future of the Human Mind: Techno-Anthropological Hybridization? Challenge 2019, 62, 77-95. [CrossRef]

51. Bergman, M.M. The World after COVID. World 2020, 1, 45-48. [CrossRef]

52. Lugo-Morin, D.R. Global Food Security in a Pandemic: The Case of the New Coronavirus (COVID-19). World 2020, 1, 171-190. [CrossRef]

53. Kirmayer, L.J.; Dandeneau, S.; Elizabeth Marshall, E.; Phillips, M.K.; Williamson, K.J. Rethinking Resilience from Indigenous Perspectives. Can. J. Psychiatry 2011, 56, 84-91. [CrossRef]

54. Ford, J.D.; King, N.; Galappaththi, E.K.; Pearce, T.; McDowell, G.; Harper, S.L. The Resilience of Indigenous Peoples to Environmental Change. One Earth 2020, 2, 532-543. [CrossRef]

55. Nagle, N.; van Oven, M.; Wilcox, S.; van Holst Pellekaan, S.; Tyler-Smith, C.; Xue, Y.; Ballantyne, K.N.; Wilcox, L.; Papac, L.; Cooke, K.; et al. Aboriginal Australian mitochondrial genome variation-an increased understanding of population antiquity and diversity. Sci. Rep. 2017, 7, 43041. [CrossRef] [PubMed]

56. Rasmussen, M.; Guo, X.; Wang, Y.; Lohmueller, K.E.; Rasmussen, S.; Albrechtsen, A.; Skotte, L.; Lindgreen, S.; Metspalu, M.; Jombart, T.; et al. An aboriginal australian genoma reveals separate human dispersals into Asia. Science 2011, 334, 94-98. [CrossRef]

57. Schlebusch, C.M.; Skoglund, P.; Sjödin, P.; Gattepaille, L.M.; Hernandez, D.; Jay, F.; Li, S.; De Jongh, M.; Singleton, A.; Blum, M.G.; et al. Genomic variation in seven Khoe-San groups reveals adaptation and complex African history. Science 2012, 338, 374-379. [CrossRef]

58. Rotimi, C.N.; Bentley, A.R.; Doumatey, A.P.; Chen, G.; Shriner, D.; Adeyemo, A. The genomic landscape of African populations in health and disease. Hum. Mol. Genet. 2017, 26, R225-R236. [CrossRef]

59. Choudhury, A.; Aron, S.; Sengupta, D.; Hazelhurst, S.; Ramsay, M. African genetic diversity provides novel insights into evolutionary history and local adaptations. Hum. Mol. Genet. 2018, 27, R209-R218. [CrossRef] [PubMed] 
60. INPI (Instituto Nacional de los Pueblos Indígenas). Atlas de los Pueblos Indígenas de México; INPI: Ciudad de Mexico, Mexico, 2020.

61. Masferrer, E. Cambio y Continuidades Entre los Totonacos de la Sierra Norte de Puebla. Tesis de maestría, Universidad Iberoamericana, Puebla, Mexico, 2006.

62. SEDESOL. Catálogo de localidades. Unidad de Microrregiones. CIBCEC-2006. Available online: www.microrregiones.gob.mx (accessed on 25 November 2020).

63. Broda, J. Ciclos agrícolas en la cosmovisión prehispánica: El ritual mexica. In Historia y Vida Ceremonial en las Comunidades Mesoamericanas: Los Ritos Agrícolas; Broda, J., Good, C., Eds.; CONACULTA-Instituto Nacional de Antropología e Historia/Universidad Nacional Autonoma de México/Instituto de Investigaciones Históricas: Ciudad de México, México, 2004; pp. 35-60.

64. Snijders, T. Estimation on the basis of snowball samples: How to weight? Bull. Méthodol. Soc. 1992, 36, 59-70. [CrossRef]

65. Briggs, J.; Sharp, J. Indigenous knowledges and development: A postcolonial caution. Third World Q. 2004, 25, 661-676. [CrossRef]

66. Briggs, J. The use of indigenous knowledge in development: Problems and challenges. Prog. Dev. Stud. 2005, 5, 99-114. [CrossRef]

67. Ellison, N. Cambios agro-ecológicos y percepción ambiental en la región Totonaca de Huehuetla, Pue (Kgoyom), Ponencia presentada en el Congreso de la Sociedad Mexicana de Antropología, México. 2001. Available online: https://nuevomundo. revues.org/302 (accessed on 12 December 2020).

68. Jackson, G.; McNamara, K.E.; Witt, B. "System of hunger": Understanding causal disaster vulnerability of indigenous food systems. J. Rural Stud. 2020, 731, 63-175. [CrossRef]

69. Apgar, M.J.; Allen, W.; Moore, K.; Ataria, J. Understanding adaptation and transformation through indigenous practice: The case of the Guna of Panama. Ecol. Soc. 2015, 20, 45. [CrossRef]

70. Fernández-Llamazares, A.; Diaz-Reviriego, I.; Luz, A.C.; Cabeza, M.; Pyhälä, A.; Reyes-Garcia, V. Rapid ecosystem change challenges the adaptive capacity of Local Environmental Knowledge. Glob. Environ. Chang. 2015, 31, 272-284. [CrossRef]

71. Carrie, H.; Mackey, T.K.; Laird, S.N. Integrating traditional indigenous medicine and western biomedicine into health systems: A review of Nicaraguan health policies and miskitu health services. Int. J. Equity Health 2015, 14, 129. [CrossRef]

72. Li, R. Indigenous identity and traditional medicine: Pharmacy at the crossroads. Can. Pharm. J. 2017, 150, 279-281. [CrossRef]

73. Hitziger, M.; Heinrich, M.; Edwards, P.; Pöll, E.; Lopez, M.; Krütli, P. Maya phytomedicine in Guatemala-Can cooperative research change ethnopharmacological paradigms. J. Ethnopharmacol. 2016, 186, 61-72. [CrossRef]

74. Richardson, J.; Lockhart, C.; Pongolini, S.; Karesh, W.B.; Baylis, M.; Goldberg, T.; Slingenbergh, J.; Gale, P.; Venturini, T.; Catchpole, M.; et al. Drivers for emerging issues in animal and plant health. EFSA J. 2016, 14, s0512. [CrossRef]

75. Puoti, C. COVID: How to explain differences in lethality between different populations? Med. Hypotheses 2020, 140, 109784 [CrossRef]

76. Challen, R.; Brooks-Pollock, E.; Read, J.M.; Dyson, L.; Tsaneva-Atanasova, K.; Danon, L. Risk of mortality in patients infected with SARS-CoV-2 variant of concern 202012/1: Matched cohort study. BMJ 2021, 372, n579. [CrossRef]

77. Del Rio, C.; Malani, P. COVID-19 in 2021-Continuing Uncertainty. JAMA 2021, 325, 1389-1390. [CrossRef]

78. Sabino, E.C.; Buss, L.F.; Carvalho, M.P.; Prete, C.A.; Crispim, M.A.; Fraiji, N.A.; Pereira, R.H.; Parag, K.V.; Peixoto, P.; Kraemer, M.U.; et al. Resurgence of COVID-19 in Manaus, Brazil, despite high seroprevalence. Lancet 2021, 397, 452-455. [CrossRef]

79. UNHRC. Relatório: Ameaças e violação de direitos humanos no Brasil: Povos indígenas isolados. Conselho de Direitos Humanos da Organização das Nações (UNHRC). 2020. Available online: https://www.socioambiental.org/sites/blog.socioambiental.org/ files/arquivos/povos_isolados_cdh_onu_relatorio_2020.pdf (accessed on 12 December 2020).

80. RRI. Who Owns the World's Land? A Global Baseline of Formally Recognized Indigenous and Community Land Rights; Rights and Resources Initiative (RRI): Washington, DC, USA, 2015.

81. Kaplan, H.S.; Trumble, B.C.; Stieglitz, J.; Mendez, R.; Cayuba, M.G.; Moye, L.M.; Alami, S.; Kraft, T.; Gutierrez, R.Q.; Adrian, J.C.; et al. Voluntary collective isolation as a best response to COVID-19 for indigenous populations? A case study and protocol from the Bolivian Amazon. Lancet 2020, 395, 1727-1734. [CrossRef]

82. Bhala, N.; Curry, G.; Martineau, A.R.; Agyemang, C.; Bhopal, R. Sharpening the global focus on ethnicity and race in the time of COVID-19. Lancet 2020, 395, 1673-1676. [CrossRef]

83. Begotti, R.A.; Peres, C.A. Rapidly escalating threats to the biodiversity and ethnocultural capital of Brazilian Indigenous Lands. Land Use Policy 2020, 96, 104694. [CrossRef]

84. IASG. The Inter-Agency Support Group on Indigenous Issues. UN Permanent Forum on Indigenous Issues. 2020. Available online: https:/ / www.un.org/development/desa/indigenouspeoples/about-us/inter-agency-support-group.html (accessed on 12 December 2020).

85. Martinez-Alvarez, M.; Jarde, A.; Usuf, E.; Brotherton, H.; Bittaye, M.; Samateh, A.L.; Antonio, M.; Vives-Tomas, J.; D'Alessandro, U.; Roca, A. COVID-19 pandemic in west Africa. Lancet Glob. Health 2020, 8, E631-E632. [CrossRef]

86. Loembé, M.M.; Tshangela, A.; Salyer, S.J.; Varma, S.J.; Ouma, A.E.; Nkengasong, J.N. COVID-19 in Africa: The spread and response. Nat. Med. 2020, 26, 999-1003. [CrossRef] [PubMed]

87. Lone, S.A.; Ahmad, A. COVID-19 pandemic-an African perspective. Emerg. Microb. Infect. 2020, 9, 1300-1308. [CrossRef]

88. Ozili, P.K. COVID-19 in Africa: Socioeconomic impact, policy response and opportunities. Int. J. Soc. Soc. Policy 2020. [CrossRef]

89. Kidia, K.K. The future of health in Zimbabwe. Glob. Health Action 2018, 11, 1496888. [CrossRef]

90. Mukasa, N. The Batwa Indigenous People of Uganda and Their Traditional Forest Land: Eviction, Non-Collaboration and Unfulfilled Needs. Indig. Policy J. 2014, 24, 1-17. 
91. Nichols-Belo, A. "Witchdoctors" in White Coats: Politics and Healing Knowledge in Tanzania. Med. Anthropol. 2018, 37, 722-736. [CrossRef] [PubMed]

92. Nieman, W.A.; Leslie, A.J.; Wilkinson, A. Traditional medicinal animal use by Xhosa and Sotho communities in the Western Cape Province, South Africa. J. Ethnobiol. Ethnomed. 2019, 15, 34. [CrossRef] [PubMed]

93. Hartley, B. Rwanda's post-genocide approach to ethnicity and its impact on the batwa as an indigenous people: An international human rights law perspective. QUT Law Rev. 2015, 15, 51-70. [CrossRef]

94. Olivero, J.; Fa, J.E.; Farfán, M.A.; Lewis, J.; Hewlett, B.; Breuer, T.; Carpaneto, G.M.; Fernández, M.; Germi, F.; Hattori, S.; et al. Distribution and Numbers of Pygmies in Central African Forests. PLoS ONE 2016, 11, e0144499. [CrossRef]

95. Wodon, Q.; Backiny-Yetna, P.; Ben-Achour, A. Indigenous Peoples in Central Africa: The Case of the Pygmies. In Indigenous Peoples, Poverty, and Development; Hall, G.H., Patrinos, H.A., Eds.; Cambridge University Press: Cambridge, UK, $2012 ;$ pp. 118-148. [CrossRef]

96. Ene-Obong, H.N.; Onuoha, N.O.; Eme, P.E. Gender roles, family relationships, and household food and nutrition security in Ohafia matrilineal society in Nigeria. Mater. Child Nutr. 2017, 13, e12506. [CrossRef] [PubMed]

97. Dieckmann, U.; Thiem, M.; Hays, J. A Brief Profile of the San in Namibia and the San Development Initiatives. Scraping the Pot': San in Namibia Two Decades after Independence; John Meinert Printing: Windhoek, Namibia, 2014; pp. 21-36.

98. Belahsen, R.; Naciri, K.; El Ibrahimi, A. Food security and women's roles in Moroccan Berber (Amazigh) society today. Mater. Child Nutr. 2017, 13, e12562. [CrossRef]

99. Lee, K. The Amazigh's Fight for Cultural Revival in the New Libya: Reclaiming and Establishing Identity Through Antiquity. Seattle J. Soc. Justice 2012, 11, 297-336.

100. Claridge, L. Litigation as a Tool for Community Empowerment: The Case of Kenya's Ogiek. Erasmus Law Rev. 2018, 11, 57-66. [CrossRef]

101. Gomashie, G.A. Language Vitality of Spanish in Equatorial Guinea: Language Use and Attitudes. Humanities 2019, 8, 33. [CrossRef]

102. Magnet, J. Indigenous Peoples in Eritrea. Ottawa Faculty of Law Working Paper No. 2018-09. 2018. Available online: https: / / papers.ssrn.com/sol3/papers.cfm?abstract_id=3159973 (accessed on 12 December 2020). [CrossRef]

103. Worku, A.M. A Review on Significant of Traditional Medicinal Plants for Human Use in Case of Ethiopia. J. Plant Pathol. Microbiol. $2019,10,484$.

104. Cotula, L. Indigenous peoples' land rights in Cameroon: Progress to date and possible futures IIED Brief Papers 2017, 1-4. Available online: http:/ / pubs.iied.org/17448IIED (accessed on 12 December 2020).

105. Falisse, J.-B.; Masino, S.; Ngenzebuhoro, R. Indigenous medicine and biomedical health care in fragile settings: Insights from Burundi. Health Policy Plan. 2018, 33, 483-493. [CrossRef]

106. Ouédraogo, I.; Nacoulma, B.M.; Hahn, K.; Thiombiano, A. Assessing ecosystem services based on indigenous knowledge in south-eastern Burkina Faso (West Africa). Int. J. Biodivers. Sci. Ecosyst. Serv. Manag. 2014, 10, 313-321. [CrossRef]

107. Loko, L.; Medegan, S.; Orobiyi, A.; Glinma, B.; Toffa, J.; Koukoui, O.; Djogbenou, L.; Gbaguidi, F. Traditional knowledge of invertebrates used for medicine and magical-religious purposes by traditional healers and indigenous populations in the Plateau Department, Republic of Benin. J. Ethnobiol. Ethnomed. 2019, 15, 66. [CrossRef]

108. Oktay, S.; Sadıkoğlu, S. The gastronomic cultures impact on the African cuisine. J. Ethnic Foods 2018, 5, 140-146. [CrossRef]

109. Arndt, C.; Davies, R.; Gabriel, S.; Harris, L.; Makrelov, K.; Robinson, S.; Levy, S.; Simbanegavi, W.; Seventer, D.; Anderson, L. Covid-19 lockdowns, income distribution, and food security: An analysis for South Africa. Global Food Secur. 2020, 26, 100410. [CrossRef]

110. Rutayisire, E.; Nkundimana, G.; Mitonga, H.K.; Boye, A.; Nikwigize, S. What works and what does not work in response to COVID-19 prevention and control in Africa. Int. J. Infect.Dis. 2020, 97, 267-269. [CrossRef]

111. Villalonga-Morales, A. Porqué es menos "intensa" la epidemia de Covid-19 en África? Rev. Esp. Anestesiol. Reanim. 2020, 67, 556-558. [CrossRef]

112. Cruickshank, M.; Shaban, R.Z. COVID-19: Lessons to be learnt from a once-in-a-century global pandemic. J. Clin. Nurs. 2020, 29, 3901-3904. [CrossRef]

113. Kamel, M.N.; Geraghty, E.M. Geographical tracking and mapping of coronavirus disease COVID-19/severe acute respiratory syndrome coronavirus 2 (SARS-CoV-2) epidemic and associated events around the world: How 21st century GIS technologies are supporting the global fight against outbreaks and epidemics. Int. J. Health Geogr. 2020, 19, 8.

114. Son, H.N.; Chi, D.T.; Kingsbury, A. Indigenous knowledge and climate change adaptation of ethnic minorities in the mountainous regions of Vietnam: A case study of the Yao people in Bac Kan Province. Agric. Syst. 2019, 176, 102683. [CrossRef]

115. Grant, P. (Ed.) State of the World's Minorities and Indigenous Peoples 2016; Minority Rights Group International (MRG): London, UK, 2015.

116. Chongchorhor, C.; Kamala, M. Using facet analytico-synthetic method for organizing Thai's indigenous rice knowledge. Kasetsart J. Soc. Sci. 2019, 40, 121-128. [CrossRef]

117. Cuaton, G.P.; Su, Y. Local-indigenous knowledge on disaster risk reduction: Insights from the Mamanwa indigenous peoples in Basey, Samar after Typhoon Haiyan in the Philippines. Int. J. Dis. Risk Reduct. 2020, 84, 101596. [CrossRef]

118. Galappaththi, E.; Ford, J.; Bennett, E. Climate change and adaptation to social-ecological change: The case of Indigenous people and culture-based fisheries in Sri Lanka. Clim. Chang. 2020, 162, 279-300. [CrossRef] 
119. Gartaula, H.; Patel, K.; Shukla, S.; Devkota, R. Indigenous knowledge of traditional foods and food literacy among youth: Insights from rural Nepal. J. Rural Stud. 2020, 73, 77-86. [CrossRef]

120. Ong, H.G.; Ling, S.M.; Mar, T.T.; Kang, D.-H.; Lee, J.-H.; Kim, Y.-D. Ethnomedicinal plants and traditional knowledge among three Chin indigenous groups in Natma Taung National Park (Myanmar). J. Ethnopharmacol. 2018, 225, 136-158. [CrossRef]

121. Frankie, K.H.; Chang, T.C.; Leung, S. The Batek's dilemma on indigenous tourism. Ann. Tour. Res. 2020, 83, 102948.

122. Resminingayu, D.H. Turbulent national identity in Laos: The hmong ethnic group as a case study. Paradig. J. Kajian Budaya 2018, 8, 186-196. [CrossRef]

123. Hammine, M. Indigenous in Japan? The Reluctance of the Japanese State to Acknowledge Indigenous Peoples and Their Need for Education. In Sámi Educational History in a Comparative International Perspective; Kortekangas, O., Keskitalo, P., Nyyssönen, J., Kotijarchuk, A., Paksuniemi, M., Sjögren, D., Eds.; Palgrave Macmillan: Cham, Switzerland, 2019; pp. $225-245$.

124. Situmorang, R.; Trilaksono, T.; Japutra, A. Friend or Foe? The complex relationship between indigenous people and policymakers regarding rural tourism in Indonesia. J. Hosp. Tour. Manag. 2019, 39, 20-29. [CrossRef]

125. Chyne, D.A.; Ananthan, R.; Longvah, T. Food compositional analysis of Indigenous foods consumed by the Khasi of Meghalaya, North-East India. J. Food Compos. Anal. 2020, 77, 91-100. [CrossRef]

126. Hunter, W.C. Syncretism and indigenous cultural tourism in Taiwan. Ann. Tour. Res. 2020, 82, 102919. [CrossRef]

127. Leemann, E. Who is the community? Governing territory through the making of 'indigenous communities' in Cambodia. Geoforum 2021, 119, 238-250. [CrossRef]

128. Bhuiyan, A.A. Indigenous Languages in Bangladesh: Loopholes behind the Scenes. Indig. Policy J. 2016, $27,1-18$.

129. OECD. Coronavirus: The World Economy at Risk. OECD Interim Economic Outlook, March Paris: Organización para la Cooperación y el Desarrollo Económico (OECD). 2020. Available online: https:/ / www.oecd.org/economic-outlook/ (accessed on 20 May 2020).

130. World Bank. Fighting COVID-19 Europe and Central Asia Economic Update (Spring); World Bank: Washington, DC, USA, 2020. [CrossRef]

131. Wiekart, R. Progress through Racial Extermination: Social Darwinism, Eugenics, and Pacifism in Germany, 1860-1918. Ger. Stud. Rev. 2003, 26, 273-294. [CrossRef]

132. Wolfe, P. Settler colonialism and the elimination of the native. J. Genocide Res. 2006, 8, 387-409. [CrossRef]

133. Aoki, C.Y.; Moreira, P.F. Many world's, many nature(s), one planet: Indigenous knowledge in the Anthropocene. Rev. Bras. Política Int. 2016, 59, e009.

134. Coates, K.S. A Global History of Indigenous People's Struggle and Survival; Palgrave Macmilla: New York, NY, USA, 2004.

135. Gaski, H. The Sami People: The "White Indians" of Scandinavia. Am. Indian Cult. Res. J. 1993, 17, 115-128. [CrossRef]

136. Kozlov, A.; Vershubsky, G.; Kozlova, M. Indigenous Peoples of Northern Russia: Anthropology and Health. Int. J. Circumpolar Health 2007, 66, 1-184. [CrossRef]

137. Lassila, M.M. Mapping mineral resources in a living land: Sami mining resistance in Ohcejohka, northern Finland. Geoforum 2018, 96, 1-9. [CrossRef]

138. Nilsson, R. The Consequences of Swedish National Law on Sámi Self-Constitution-The Shift from a Relational Understanding of Who Is Sámi Toward a Rights-Based Understanding. Ethnopolitics 2020, 19, 292-310. [CrossRef]

139. Badr, H.; Du, H.; Marshall, M.; Dong, E.; Squire, M.M.; Gardner, L.M. Association between mobility patterns and COVID-19 transmission in the USA: A mathematical modelling study. Lancet Infect. Dis. 2020, 20, 1247-1254. [CrossRef]

140. Holshue, M.L.; DeBolt, C.; Lindquist, S.; Lofy, K.H.; Wiesman, J.; Bruce, H.; Spitters, C.; Ericson, K.; Wilkerson, S.; Tural, A.; et al. First Case of 2019 Novel Coronavirus in the United States. N. Engl. J. Med. 2020, 382, 929-936. [CrossRef]

141. Maxmen, A. Thousands of coronavirus tests are going unused in US labs. Nature 2020, 580, 312-313. [CrossRef] [PubMed]

142. Miller, M.J.; Loaiza, J.R.; Takyar, A.; Gilman, R.H. COVID-19 in Latin America: Novel transmission dynamics for a global pandemic? PLoS Negl. Trop. Dis. 2020, 14, e0008265. [CrossRef]

143. ECLAC. Measuring the Impact of COVID-19 with a View to Reactivation. Special Report $N^{\circ}$ 2. Economic Commission for Latin America and the Caribbean (ECLAC); ECLAC: Santiago, Chile, 2020.

144. Rubin, R.; Abbasi, J.; Voelker, R. Latin America and Its Global Partners Toil to Procure Medical Supplies as COVID-19 Pushes the Region to Its Limit. JAMA 2020, 324, 217-219. [CrossRef]

145. Cimerman, S.; Chebabo, A.; DaCunha, C.A.; Rodriguez-Morales, A.J. Deep impact of COVID-19 in the healthcare of Latin America: The case of Brazil. Braz. J. Infect. Dis. 2020, 24, 93-95. [CrossRef] [PubMed]

146. ISA. The Impacts of the Pandemic on the Yanomami Indigenous Territory. São Paulo: Instituto Socioambiental. 2020. Available online: https:/ / acervo.socioambiental.org/acervo/publicacoes-isa/impacts-pandemic-yanomami-indigenous-territoryminersoutcovidout (accessed on 12 December 2020).

147. Huertas, B. The Importance of Ethics, Respect for Self-determination and the Fundamental Rights of Isolated Indigenous People in Anthropology. Rev. Antropol. 2021, 8, 85-104.

148. Ossola, M.M. Usos y resignificaciones de las lenguas wichí y español entre jóvenes universitarios bilingües (Salta, Argentina). Cuad. Antropol. Soc. 2018, 47, 55-69.

149. McBride, K.E.; Brown, K.G.; Fisher, O.M.; Steffens, D.; Yeo, D.A.; Koh, C.E. Impact of the COVID-19 pandemic on surgical services: Early experiences at a nominated COVID-19 centre. ANZ J. Surg. 2020, 90, 663-665. [CrossRef] [PubMed]

150. Wilson, S. Pandemic leadership: Lessons from New Zealand's approach to COVID-19. Leadership 2020, 6, 279-293. [CrossRef] 
151. Henrickson, M. Kiwis and COVID-19: The Aotearoa New Zealand Response to the Global Pandemic. Int. J. Community Soc. Dev. 2020, 2, 121-133. [CrossRef]

152. McMeeking, S.; Leahy, H.; Savage, C. An indigenous self-determination social movement response to COVID-19. AlterNative 2020, 16, 395-398. [CrossRef]

153. Filer, C. Interdisciplinary perspectives on historical Ecology and environmental policy in Papua New Guinea. Environ. Conserv. 2011, 38, 256-269. [CrossRef]

154. Radcliffe, C.; Parissi, C.; Raman, A. Valuing Indigenous Knowledge in the Highlands of Papua New Guinea: A Model for Agricultural and Environmental Education. Aust. J. Environ. Educ. 2016, 32, 243-259. [CrossRef]

155. Cargo, M.; Potaka-Osborne, G.; Cvitanovic, L.; Warner, L.; Clarke, S.; Judd, J.; Chakraborty, A.; Boulton, A. Strategies to support culturally safe health and wellbeing evaluations in Indigenous settings in Australia and New Zealand: A concept mapping study. Int. J. Equity Health 2019, 18, 194. [CrossRef] [PubMed]

156. Zalcberg, J. The Kanak indigenous peoples of New Caledonia: Decolonization and self-determination in practice. In Statehood and Self-Determination: Reconciling Tradition and Modernity in International Law; French, D., Ed.; Cambridge University Press: Cambridge, UK, 2013; pp. 377-406.

157. Grine, F.E.; Fleagle, J.G. The First Humans: A Summary Perspective on the Origin and Early Evolution of the Genus Homo. In The First Humans-Origin and Early Evolution of the Genus Homo. Vertebrate Paleobiology and Paleoanthropology; Grine, F.E., Fleagle, J.G., Leakey, R.E., Eds.; Springer: Dordrecht, The Netherlands, 2009. [CrossRef]

158. Ginsburg, S.; Jablonka, E. Evolutionary transitions in learning and cognition. Philos. Trans. R. Soc. B Biol. Sci. 2021, $376,20190766$. [CrossRef] [PubMed]

159. Sirugo, G.; Williams, S.M.; Tishkoff, S.A. The Missing Diversity in Human Genetic Studies. Cell 2019, 177, 26-31. [CrossRef]

160. Rotimi, C.N.; Adeyemo, A.A. From one human genome to a complex tapestry of ancestry. Nature 2021, 590, 220-221. [CrossRef] 